\title{
A Record of Uranium-Series Transport at Nopal I, Sierra Peña Blanca, Mexico: Implications for Natural Uranium Deposits and Radioactive Waste Repositories
}

\author{
J.S. Denton ${ }^{1 *}$, S.J. Goldstein ${ }^{1}$, P.Paviet ${ }^{2}$, A.J. Nunn ${ }^{1}$, R.S. Amato ${ }^{1}$, K.A. Hinrichs ${ }^{1}$ \\ ${ }^{1}$ Nuclear and Radiochemistry (C-NR), Los Alamos National Laboratory, MS J514, PO Box \\ 1663, Los Alamos, New Mexico 87545 \\ ${ }^{2}$ Department of Energy, Office of Nuclear Energy, 19901 Germantown Road, Germantown, \\ Maryland 20874 \\ *Corresponding author: jdenton@lanl.gov
}

\begin{abstract}
Studies of uranium-series (U-series) disequilibria within and around ore deposits provide valuable information on the extent and timing of actinide mobility, via mineral-fluid interaction, over a range of spatial and temporal scales. Such information is useful in studies of analogs of high-level nuclear-waste repositories, as well as for mining and mineral extraction sites, locations of previous nuclear weapons testing, and legacy nuclear waste contamination. In this study we present isotope dilution mass spectrometry U-series measurements for fracture-fill materials (hematite, goethite, kaolinite, calcite, dolomite and quartz) from one such analog; the Nopal I uranium ore deposit situated at Peña Blanca in the Chihuahua region of northern Mexico. The ore deposit is located in fractured, unsaturated volcanic tuff and fracture-fill materials from surface fractures as well as fractures in a vertical drill core have been analyzed. High uranium concentrations in the fracture-fill materials (between 12 and $7700 \mathrm{ppm}$ ) indicate uranium mobility and transport from the deposit. Uranium concentrations generally decrease with horizontal distance away from the deposit but in this deposit there is no trend with depth below the surface.
\end{abstract}

Isotopic activity ratios, ${ }^{238} \mathrm{U}_{-}{ }^{234} \mathrm{U}-{ }^{230} \mathrm{Th}-{ }^{232} \mathrm{Th}$ linear age trends, and U-Th-Pa model ages indicate an actinide mobility evolution that can be characterized as complex and varied. There is evidence of both open and closed system behavior for uranium, depending on both sample and time-scale. The ${ }^{234} \mathrm{U} /{ }^{238} \mathrm{U}$ activity ratios indicate $\mathrm{U}$ mobility from 1.2-0.2 Ma. In the last 0.2 Ma there is isotopic evidence for some $\mathrm{U}$ mobility but mostly $\mathrm{U}$ immobility. In almost all cases the Th-Pa radionuclides studied here have been immobile for the past $200 \mathrm{ka}$. Radium appears to have been recently $(0.1-8 \mathrm{ka})$ mobile due to ongoing fluid flow in the fractures. Overall, the mainly closed system behavior for U-Th-Pa over the past $\sim 200$ ka provides an indicator of the geochemical immobility of these actinides over time-scales relevant for potential nuclear waste repositories situated in fractured, unsaturated tuff.

Keywords: U-series, mass spectrometry, analog site, radioactive waste, Peña Blanca 


\section{Introduction}

The purpose of this study is to evaluate radionuclide migration from a natural uranium deposit (Nopal I) situated at Peña Blanca, Chihuahua, Mexico (Figure 1). The evaluation is carried out by conducting isotope dilution measurements on secondary fracture-fill bulk samples. The uranium deposit is just one of dozens of sites of uranium mineralization found in northern Mexico (George-Aniel et al., 1991; Dobson et al., 2008). The origin of the deposit has been dated to $32 \mathrm{Ma}$ and the deposit has been extensively studied since it provides clues to the likely radionuclide transport from a high-level nuclear-waste repository situated in similar geology (e.g. Goodell et al., 1981; Leslie et al., 1993, 1999; Pearcy et al., 1994, 1995; Prikryl et al., 1997; Pickett and Murphy, 1999; Fayek et al., 2006; Calas et al., 2008; Dobson et al., 2008, 2012; Ku et al., 2009; Goldstein et al., 2010). The results from the current study are also intended to advance understanding of actinide mobility from sites of previous or currently active uranium mining (e.g. Chakraborty et al., 2010), nuclear weapons testing (e.g. Paces et al., 2013), nuclear industry contamination (e.g. Um et al., 2010), and nuclear accidents (Salbu et al., 1994).

\subsection{Environmental mobility of $U$-series radionuclides}

Uranium is naturally present as one of three isotopes $\left({ }^{238} \mathrm{U},{ }^{235} \mathrm{U}\right.$ and $\left.{ }^{234} \mathrm{U}\right)$, and in one of two primary oxidation states, U(VI) and U(IV). Each of these has a very different solubility in water. The U(VI) ion is highly soluble, existing in aqueous systems as the uranyl ion $\left(\mathrm{UO}_{2}{ }^{2+}\right)$. In contrast the $\mathrm{U}(\mathrm{IV})$ is found as the $\mathrm{U}^{4+}$ ion and is only weakly soluble (e.g. Duff et al., 1999; Stirling et al., 2007). As a result, the U(VI) uranyl ion is more mobile, forming soluble complexes with inorganic (e.g. hydroxyl, sulfate, carbonate, and phosphate ions) and organic ligands (e.g. Langmuir, 1978; Ho and Miller, 1985, 1986 Lienert et al., 1994; Gabriel et al., 1998; Vodyanitskii, 2011).

The level of uranium mobility depends on processes that fix the ions in place. These processes include sorption to solid particles and also the precipitation of U-bearing secondary minerals via conversion of U(VI) ions to U(IV) ions as a result of reduction (e.g. Morse and Choppin, 1991; Wersin et al., 1994). In general, dissolved uranium sorbs to Fe-oxide, manganese and clay minerals as well as organic matter unless high levels of complexing ligands are present (e.g. Koppi et al., 1996; Chisholm-Brause et al., 2001; Duff et al., 2002; Chakraborty et al., 2010; Sachs and Bernhard, 2011; Li et al., 2014). The reduction of U(VI) to U(IV) by abiotic (e.g. hematite and clay minerals) and biotic reductants (e.g. Shewanella spp.) can lead to long-term uranium immobilization and has been the focus of many previous studies into the remediation of contaminated sites (e.g. Duff et al., 1999; Lloyd and Renshaw, 2005 and references therein; Merroun and Selenska Pobell, 2008 and references therein; Chakraborty et al., 2010; Gavrilescu et al., 2009 and references therein).

Thorium, in contrast to uranium, has only one stable oxidation state, Th(IV), and is often present as thorianite $\left(\mathrm{ThO}_{2}\right)$ (e.g. Langmuir and Herman, 1980; Natrajan et al., 2014). Since thorianite has low solubility and strong sorption characteristics, thorium concentration in water is low (e.g. Langmuir and Herman, 1980; Krishnaswami et al., 1982; Porcelli and Swarzenski, 2003). In addition, thorium reacts readily with particles and is more strongly sorbed than $\mathrm{U}$ (Porcelli and 
Swarzenski, 2003). As a result, thorium mobility in groundwater is usually the result of particle movement, upon which Th is adsorbed (Cowart and Burnett, 1994 and references therein).

In aqueous environments protactinium exists in the +4 and +5 oxidation states (Guillaumont et al., 1996). At its most stable, the oxidized $\mathrm{PaO}^{3+}$ ion exhibits hydrolysis and sorption on solid surfaces (Natrajan et al., 2014).

Radium is chemically analogous to $\mathrm{Ba}$ and $\mathrm{Ca}$ and only exists in the +2 oxidation state. Radium mobility is linked to its complexing with chloride but may be inhibited due to the coprecipitation of radium sulfate with barium sulfate (i.e. barite, Cowart and Burnett, 1994 and references therein). Particulate and colloidal transport involving clays and iron hydroxides may play a role in $\mathrm{Ra}$ transport although $\mathrm{Ra}$ is generally unlikely to bind with organic ligands. (Porcelli and Swarzenski, 2003 and references therein).

\subsection{U-series disequilibria dating}

Differences in chemical behavior between the members of the $U$ and Th decay chains, outlined in Section 1.1, may lead to radioactive disequilibria between parent and daughter nuclides. One other potential driver of radioactive disequilibria is alpha-recoil. This is thought to arise due to the radioactive decay of ${ }^{238} \mathrm{U}$ to ${ }^{234} \mathrm{U}$ (via ${ }^{234} \mathrm{Th}$ and ${ }^{234} \mathrm{~Pa}$ ) through the emission of a single $\alpha$ particle and a pair of $\beta$-particles. As a result, there may be damage to the crystal lattice and the ${ }^{234} \mathrm{U}$ daughter may be more susceptible to oxidation and leaching than the ${ }^{238} \mathrm{U}$ parent, which remains bound in the lattice (Kigoshi, 1971). The daughter ${ }^{234} \mathrm{U}$ may even be directly released into the surrounding medium if the grain size of the mineral is sufficiently small (De Paolo et al., 2006).

In order to evaluate the time of occurrence of a disequilibrium event in a closed system it is simply necessary to measure the extent to which the isotope system has returned to equilibrium (secular equilibrium). Only measurements of parent nuclide $\left({ }^{238} \mathrm{U},{ }^{235} \mathrm{U}\right.$, and ${ }^{232} \mathrm{Th}$ ) activities and their ratios with the activities of daughter nuclides (e.g. ${ }^{234} \mathrm{U},{ }^{230} \mathrm{Th},{ }^{226} \mathrm{Ra}$, and ${ }^{231} \mathrm{~Pa}$ ) are required (e.g. Ivanovich, 1992 and references therein). This technique has been applied to secondary uranium minerals in a number of previous studies (e.g. MacKenzie et al., 1992; Kaufman et al., 1995; Prikryl et al., 1997; Dawood, 2001; Fayek et al., 2006; Drake et al., 2009; and Paces et al., 2013). U-series disequilibria are generally observed representing U mobility in the last 1 million years. Uranium removal at the surface and deposition at depth below the redox front has been observed (e.g. MacKenzie et al. (1992), Drake et al. (2009)). However at sites in similar environments to Peña Blanca, e.g. Pahute Mesa, Nevada, the isotopic results suggest a steadystate system with respect to $U$ input and removal requiring stable hydrological and geochemical processes for the past 0.5-1 million years (Paces et al., 2013).

Over the past few decades, U-series measurements have transitioned from traditional decay counting techniques towards more precise mass spectrometric techniques. These techniques include multi-collector thermal ionization mass spectrometry (MC-TIMS) and multi-collector inductively coupled plasma mass spectrometry (MC-ICP-MS) (e.g. Goldstein and Stirling, 2003). More recently microanalytical techniques such as laser ablation inductively coupled plasma mass spectrometry (LA-ICP-MS) (e.g. Stirling et al., 2000; Eggins et al., 2005; Mertz- 
Kraus et al., 2010; Benson et al., 2013) and secondary ion mass spectrometry (SIMS) (e.g. Layne and Sims, 2000; Fayek et al., 2006; Vazquez and Lidzbarski, 2012) have also been successfully employed.

\subsection{Analog studies at Peña Blanca}

Analog studies enable the fate of radionuclides from natural uranium ore deposits, in environments similar to those for planned high-level waste repositories, to be assessed over long/geological timescales. Examples of analog sites include Peña Blanca, Mexico, Alligator Rivers, Australia and Palmottu, Finland (Payne and Airey, 2006 and references therein; Pomiés et al., 2004). In general, natural analog sites have a wide range of characteristics in terms of geology, hydrology, uranium geochemistry, and age.

The Nopal I ore deposit at Peña Blanca in northern Mexico (Figure 1) has been of particular interest because it has a similar climate, hydrology and geology to Yucca Mountain (a potential site for US high-level nuclear-waste storage). Both locations are part of Basin and Range horsts, within semi-arid to arid regions, and the Peña Blanca ore and Yucca Mountain repository horizon are both in the oxidizing, unsaturated zone (Pearcy et al., 1994). The tuffs at both Yucca Mountain and Peña Blanca are fractured, although there is U-series evidence from Yucca Mountain that pore fluid flow through unfractured tuff is also an important mechanism for uranium mobility (Gascoyne et al., 2002). U-series analysis of secondary minerals (calcite and opal) in the fractures at Yucca Mountain suggest the fracture pathways have been active with slow secondary mineral deposition rates since the eruption of the 12.8 Ma host tuff to the present day (Neymark and Paces, 2000; Neymark and Amelin, 2008). The deposition rate is unlikely to have been constant with variations suggested to have been the result of changes in Pleistocene climate. Opal growth rates were faster during wetter periods and slower (with possibly no growth) during modern arid conditions (Paces et al., 2004).

At Nopal I the natural uranium deposit (uraninite) extends approximately $100 \mathrm{~m}$ vertically (deepest mine workings) in fractured rhyolitic tuff (George-Aniel et al. (1985); Pikryl et al., 1997). The deposit is generally interpreted as having been deposited at $232 \mathrm{Ma}$ during alteration of welded ash-flow tuffs (Pearcy et al., 1994; Fayek et al., 2006; Calas et al., 2008). Natural uraninite (nominally $\mathrm{UO}_{2+\mathrm{x}}$ ) is generally considered to be a highly suitable analog material to compare and contrast with potential spent nuclear fuel (e.g. Finch and Ewing, 1989; Janeczek and Ewing, 1992). The original deposit of uraninite at Nopal I has almost completely evolved into secondary products including uranyl oxyhydroxides and uranyl silicates, which are highly similar to the minerals found following corrosion experiments using spent fuel (George-Aniel et al., 1991; Pearcy et al., 1994). Fayek et al. (2006) dated some of these secondary minerals including uranophane, uraninite, schoepite and weeksite/boltwoodite by U-Pb dating using SIMS. They recorded a timeline of changing redox conditions over the past $3 \mathrm{Ma}$.

The Peña Blanca site hosted a number of studies designed to understand the history of the area (e.g. Rodriguez Torres et al., 1976; Goodell, 1981, 1985; McDowell and Mauger, 1994; ReyesCortés, 1997, 2002; McDowell, 2007; Fayek et al., 2006; Dobson et al., 2008). In 2003 three wells were drilled at the Nopal I site (PB-1, PB-2 and PB-3). The PB-1 well is located on the edge of the ore deposit with PB-2 and PB-3 approximately $50 \mathrm{~m}$ away. These distant wells 
provide access to groundwater and permit the calculation of chemical gradients. PB-1 was drilled to additionally study the geology (Dobson et al., 2008). Most of the fractures encountered in the PB-1 core were found to be mineralized and steeply dipping $\left(>60^{\circ}\right)$ (Dobson et al., 2008). From measurements of U-series nuclides in groundwater in these wells and others, Goldstein et al. (2010) showed that actinide mobility in the oxidized saturated zone was generally low at the Nopal I site and decreased in the order $\mathrm{U} \sim \mathrm{Ra} \gg>\mathrm{Th} \sim \mathrm{Pu}$.

Previous studies have also focused on understanding the uranium transport in the shallow unsaturated zone through groundwater analysis (e.g. Ghezzehei et al., 2006; Ku et al., 2009; Goldstein et al., 2010; Dobson et al., 2012) and through analysis of fracture-filling materials (e.g. Pearcy et al., 1995; Prikryl et al., 1997). Hydrological studies reveal the existence of fast flow paths possibly linked to fractures, but generally an 1-6 month delay between the start of the rainy season and subsequent seepage (Dobson et al., 2012). Further analysis revealed that the seepage water $U$ abundance and isotope ratios were non-steady state and intermittent in nature, with dissolution inputs of approximately $1 \mathrm{ppb}$ of dissolved $\mathrm{U}$ per day from the ore deposit $(K u$ et al., 2009; Goldstein et al., 2010). Hydrological studies of nearby uranium ore deposits have shown similar results and found that the retardation factor for uranium relative to local groundwater varies between 100 and 1000 (Montúfar et al., 2012).

Pearcy et al. (1995) extensively documented the surface fracture network surrounding the Nopal I deposit. They demonstrated uranium mobility over the last $1 \mathrm{Ma}$ particularly around $54 \mathrm{ka}$ and preferentially along the largest fractures (Pearcy et al., 1995). This led to studies by Prikryl et al. (1997) who also observed that uranium in the fractures decreased with distance from the ore deposit. The authors dated the transport to have occurred in the past $1 \mathrm{Ma}$ and concluded that the transport proceeded primarily through a multi-stage mechanism of secondary mineral growth and uranium sorption (Prikryl et al., 1997). The formation of uraninite $25 \mathrm{~m}$ above the water table, which is found at $222.6 \mathrm{~m}$ depth in PB-1 (Dobson et al., 2008) has been dated at <1 Ma (Fayek et al., 2006). It has been suggested that links between the uraninite and anatase $\left(\mathrm{TiO}_{2}\right)$ at depth indicate the presence of a barrier that removed the transported uranium before it arrived at the water table (Fayek et al., 2006).

In this study we measured long-lived U-series nuclide abundances $\left({ }^{238} \mathrm{U}_{-}{ }^{234} \mathrm{U}_{-}{ }^{230} \mathrm{Th}-{ }^{226} \mathrm{Ra}\right.$ and ${ }^{235} \mathrm{U}_{-}{ }^{231} \mathrm{~Pa}$ ), by high precision mass spectrometric methods, in samples of fracture-fill materials. These samples were identified from fractures at various distances away from the ore deposit both horizontally along the surface and below the surface from the PB-1 drill core. The isotopic results from the surface fracture samples extend those of previous isotope dilution/alpha spectrometry studies (e.g. Prikryl et al., 1997) by providing time constraints for the most recent 10,000 years through the analysis of daughter isotopes such as ${ }^{231} \mathrm{~Pa}$ and ${ }^{226} \mathrm{Ra}$. Data from the drill core fractures are, to the best of our knowledge, the first U-series data taken from fracturefill materials below the surface. These data enable us to characterize the geochemical evolution of the deposit in three dimensions. Improvements in analytical precision obtained through use of mass spectrometry enable us to identify U-series disequilibria in samples with activity ratios very close to 1 . The improved precision also reduces uncertainties associated with calculated sample U-Th-Pa model ages. We also intend to construct ${ }^{238} \mathrm{U}_{-}{ }^{234} \mathrm{U}_{-}{ }^{230} \mathrm{Th}^{2}{ }^{232} \mathrm{Th}$ isochrons, which together with the calculated sample U-Th-Pa model ages will allow us to place constraints on the extent and timing of actinide mobility in fractures in the unsaturated zone. These results 
therefore have important implications for contaminant transport from uranium ore deposits as well as the potential stability and suitability of possible nuclear waste repositories situated in this type of environment over timescales up to $1 \mathrm{Ma}$.

\section{Nopal I deposit geology and samples}

Rhyolitic tuffs (35-44 Ma) overlie the Pozos conglomerate (53 Ma), which in turn overlies Cretaceous limestones throughout the Sierra Peña Blanca. The Nopal I uranium ore was deposited in the upper most rhyolitic formations, which are dominated by welded ash-flow tuffs and weakly-welded ash-flow tuffs that are lithic-rich (Alba and Chavez, 1974; Calas, 1977; Goodell, 1981; Calas et al., 2008). It has been proposed that alteration of the Stage 1 uraninite subsequently led to the precipitation of Stage 2 uranium minerals such as weeksite, uranophane and schoepite (Fayek et al., 2006).

The PB-1 core was drilled in 2003 vertically to a depth of $250 \mathrm{~m}$ below the surface. The core was drilled adjacent to, but not through the deposit (see Figure 2). Previously, Dobson et al. (2008) gave a detailed account of the stratigraphy of core PB-1 (Figure 3). Four main stratigraphic units were identified in the PB-1 core: (i) the Nopal Formation $(0.00 \mathrm{~m}$ to $22.30 \mathrm{~m})$ consisting of a dense rhyolitic ash-flow tuff that is crystal-rich; (ii) the Colorados Formation $(22.30 \mathrm{~m}-136.38$ $\mathrm{m})$ comprised of ash-flow tuff that is rhyolitic in composition, lithic-rich and welded; (iii) the Pozos Formation (136.38 m - $244.40 \mathrm{~m}$ ), which is a conglomerate with sandstone interbedding; (iv) the Cretaceous limestone basement $(244.40 \mathrm{~m}-250.00 \mathrm{~m})$ that is formed of limestone, which is fine-grained (Dobson et al., 2008). The alteration dated by Fayek et al. (2006) within the ore deposit likely also resulted in secondary $U$ minerals being deposited along fractures in the surrounding tuff.

In the current study, surface fracture-fill samples were collected from major fractures outlined in Pearcy et al. (1995) and shown in Figure 2 (Fractures B, C, E and F). The fracture-fill materials were sampled directly from these open fractures resulting in very little host rock contamination. Since the host rock contains 8-14 ppm uranium, greater than one order of magnitude (and often 2-3 orders of magnitude) lower U concentration than most samples (see Section 3 and Leslie et al., 1993), any effect from host rock contamination can be discounted. X-Y-Z locations for the samples are given in the Appendix relative to the base map developed by Southwest Research Institute (Figure 2). Distances along the fracture from the fracture origin (the end of the fracture closest to the ore deposit) are also given in the Appendix (ranging from 0 to $38.7 \mathrm{~m}$ ). In most cases these distances represent distance from the ore deposit, however, it can be seen in Figure 2 that the origin of Fracture $\mathrm{E}$ is some distance from the ore deposit. In the current study, in some cases, different sub-samples were measured from the same sample, denoted $-\mathrm{n}$ in the tables. In other cases, a single sample was ground and different powder aliquots were dissolved and analyzed (denoted -pd1 and -pd 2 in the tables). Finally, different solution aliquots (denoted -sd1, -sd2, or -sd3) of a single-powder aliquot of a single sample were also analyzed. We expect that the U-series concentrations and element-isotope ratios should be identical to each other within errors for the solution aliquots but could differ for the sub-samples and powder aliquots, which were not homogeneous. This is generally evident in the results tables. 
In addition to the surface samples, fracture-filling materials from the PB1 core samples were also collected. Samples from the Nopal Formation (at $8.5 \mathrm{~m}$ ), the Colorados Formation (at $67 \mathrm{~m}$ ) and the Pozos Formation (at $191 \mathrm{~m}$ ) (Figure 3) were chosen for a number of reasons; (i) the variety of fracture-filling materials present, (ii) a range of depths, and (iii) the presence of a reasonably high uranium content, especially in the deepest parts of the core as shown by the gamma log in Dobson et al. (2008). These fractures were assumed to be closed and sampling was achieved by carefully separating the fracture-fill material from the host rock using a chisel and where necessary a hammer. Care was taken to avoid sampling the host rock with the fracture-fill material. The photographs in Figure 3 show that the fracture-fill materials were well-defined (top part of sample at $8.5 \mathrm{~m}$ ) or thick (majority of sample at $67 \mathrm{~m}$ and $191 \mathrm{~m}$ ). This meant that in most cases sampling of fracture-fill material was easily accomplished and host rock contamination was avoided. The fracture-filling materials have previously been shown to contain uranium and non-uranium minerals so three to four different colored fractions/sub-samples were selected from each sample for chemical and isotopic analysis (further information on the subsamples can be found in the Appendix). The aim of this was not specifically to understand uranium partitioning between minerals but to obtain variable uranium concentrations and U/Th ratios, enabling us to construct ${ }^{238} \mathrm{U}_{-}{ }^{234} \mathrm{U}_{-}{ }^{230} \mathrm{Th}^{2}{ }^{232} \mathrm{Th}$ isochrons. This would provide an improved and independent way to determine the age of fracture closure to U-Th mobility.

\section{Method}

\subsection{Surface fractures}

Samples from the surface fractures were crushed into a powder using a pestle and mortar and weighed. Rock standards TML (a Pliocene latite lava from Sonora, California) and BL-4 (a Canadian uranium ore) were already obtained as fine powders and were directly dissolved. The sample and standard rock powders were dissolved in $\mathrm{HCl}, \mathrm{HF}, \mathrm{HNO}_{3}, \mathrm{HClO}_{4}$, and $\mathrm{H}_{3} \mathrm{BO}_{3}$, redissolved in $3 \mathrm{M} \mathrm{HCl}$, and centrifuged to ensure complete dissolution. The final stock solutions were made up in $3 \mathrm{M} \mathrm{HCl}$ and stored in polyethylene bottles.

Separate aliquots of the stock solutions were spiked with a ${ }^{233} \mathrm{U}_{-}{ }^{236} \mathrm{U}$ double spike and ${ }^{229} \mathrm{Th}$ spike for determination of $U$ and Th concentrations and isotopics, ${ }^{228} \mathrm{Ra}$ tracer for measurement of ${ }^{226} \mathrm{Ra}$, and ${ }^{233} \mathrm{~Pa}$ tracer for measurement of ${ }^{231} \mathrm{~Pa}$. After sample-spike equilibration, samples were purified for $\mathrm{U}, \mathrm{Th}, \mathrm{Ra}$, and $\mathrm{Pa}$ by ion exchange chromatography using previously published methods (Goldstein et al., 1989; Volpe et al., 1991; Pickett et al., 1994; Goldstein and Stirling, 2003).

Uranium measurements were carried out using a Sector 54 MC-TIMS (VG Instruments). Following chemical purification, the uranium fractions were loaded onto tantalum side filaments. The samples were run in a triple configuration with a rhenium center filament in dynamic multicollector mode using a single Daly and multiple Faraday collectors. The total U contributions measured in the blanks produced generally negligible corrections ( $2 \mathrm{ng}, \leq 1.0 \%$ of smallest sample), and the data were corrected for these blanks. Mass-dependent instrument fractionation was corrected using the known ${ }^{233} \mathrm{U} /{ }^{236} \mathrm{U}$ ratio of the double spike. 
Thorium measurements were also carried out using the Sector 54 MC-TIMS following standard procedures in our laboratory (Denton et al., 2013). Following chemical purification, the thorium fractions were loaded onto a rhenium side filament. The samples were run in a double configuration with a rhenium center filament. The center filament was constructed using a ceramic holder in order to reduce alkali signals. Spiked procedural blanks were measured on the Daly collector as $16 \mathrm{pg}$, which was typically $<0.02 \%$ of the smallest sample. The data were corrected for these blanks.

Radium measurements were obtained on a modified NBS-12-90 instrument following standard methods in our laboratory (Volpe et al., 1991). The ${ }^{226} \mathrm{Ra} /{ }^{228} \mathrm{Ra}$ for the unspiked sample was calculated from the U/Th ratio of the sample and the assumption of secular equilibrium for these short half-lived nuclides. No ${ }^{226} \mathrm{Ra}$ blank was detected in spiked blanks. Protactinium measurements were obtained on the same instrument following standard methods in our laboratory (Pickett et al., 1994). An apparent ${ }^{231} \mathrm{~Pa}$ blank of 0.1 amole $(<0.001 \%$ of smallest sample) from small organic isobaric interferences was used to correct the data.

\subsection{Drill core}

Sub-samples from the drill core were crushed into a powder using a stainless steel pestle and mortar and weighed. The powders were then dissolved in $\mathrm{HCl}, \mathrm{HF}, \mathrm{HNO}_{3}, \mathrm{HClO}_{4}$, and $\mathrm{H}_{3} \mathrm{BO}_{3}$ to form sub-sample stock solutions. Separate aliquots from the stock solutions were mixed with ${ }^{233} \mathrm{U}$ and ${ }^{229} \mathrm{Th}$ spikes and allowed to equilibrate overnight with a small volume of $\mathrm{HClO}_{4}$. After fuming the spiked solutions with $\mathrm{HClO}_{4}$ and subsequent evaporation to dryness, uranium and thorium were separated by ion exchange chromatography using previously published methods (Denton et al., 2013).

Uranium measurements were carried out as described above for the surface fractures. For the drill core samples, the total $\mathrm{U}$ contributions measured in the blanks produced negligible corrections $(<2 \mathrm{ng}, \leq 0.4 \%$ of smallest sample) and the data were corrected for these blanks. Thorium measurements were carried out using a Plasma II MC-ICP-MS (Nu Instruments). Samples were introduced using an Aridus II desolvating nebulizer (Cetac Technologies), which reduced the oxide level and improved sensitivity. The Aridus II was also equipped with the QuickWash module to reduce washout times. Nickel cones were used in the analysis. Thorium data were collected in dynamic mode using Faraday cups and one of the ion counters (IC). The IC has a filter to improve abundance sensitivity $\left(<0.2 \mathrm{ppm}{ }^{230} \mathrm{Th} /{ }^{232} \mathrm{Th}\right)$. A gravimetric Th mix standard spiked with ${ }^{229} \mathrm{Th}$ was used to bracket the samples. The total Th contributions measured in the blanks produced negligible corrections $(0.1 \mathrm{ng}, \leq 1 \%$ of smallest sample), which were applied to the data.

\subsection{Data reduction and quantification}

All concentration and isotopic data were calculated following correction of the raw data. Corrections included blanks, IC-Faraday gains, dead times, and mass bias. Activities, denoted in the figures and tables by parentheses, were calculated using the decay constants shown in Table 1 . 


\subsection{Quality checks}

Results for the rock standards TML and BL-4 (Tables 2 and 3) provide an indication of the accuracy and reproducibility of our results. The recommended $U$ concentration for uranium ore standard BL-4 is $0.173 \%$ (Ingles et al., 1977), in good agreement with our measured value of $0.1714 \%$. The informational value for Th concentration is given as $14 \mathrm{ppm}$, in general agreement with our more precise value of $12.2 \mathrm{ppm}$. The measurements for TML agree with prior measurements in our laboratory (e.g. Goldstein et al., 1989; Cooper et al., 2003). Results for both BL-4 and TML are generally within estimated 2-sigma error of secular equilibrium for ${ }^{238} \mathrm{U}$ ${ }^{234} \mathrm{U}_{-}{ }^{230} \mathrm{Th}_{-}{ }^{226} \mathrm{Ra}$ and ${ }^{235} \mathrm{U}_{-}{ }^{231} \mathrm{~Pa} .{ }^{238} \mathrm{U}_{-}{ }^{234} \mathrm{U}_{-}{ }^{230} \mathrm{Th}$ results for TML have previously been shown to be in secular equilibrium (e.g. Goldstein et al., 1989; Cooper et al., 2003). Our solution replicate results for TML listed in the Tables provide an estimate of the measurement reproducibility. The reproducibility is $0.09 \%(2 \mathrm{xSEM})$ for uranium concentration. This is comparable or lower than the estimated precision of the uranium concentration measurements for single samples $(0.09$ $0.61 \%)$.

\section{Results}

In general, $\mathrm{U}$ concentrations in the fracture-fill materials are quite high, ranging from 12 to 7700 ppm (Table 2). Uranium concentration in the surface fractures generally decreases with increased distance along the fracture (Figure 4). This corroborates previous radiometric measurements by Pearcy et al. (1995) and Prikryl et al. (1997). For example, U concentration in fracture B (Figure 4b) corresponds to the $13.5 \mathrm{~m} \mathrm{~N}$ fracture set studied by Pearcy et al. (1995) and Prikryl et al. (1997) and decreases from $5500 \mathrm{ppm}$ at the fracture origin/within the deposit to levels of around 100-300 ppm $\sim 20 \mathrm{~m}$ away from the deposit. The value at $21.5 \mathrm{~m}$ away is however still significantly higher than that measured in the host tuff (8-14 ppm, Leslie et al., 1993). The concentration of uranium also decreases with distance from the deposit in other fractures (Figure $4 \mathrm{c}$ and d) but fewer samples have been analyzed, limiting the conclusions that can be drawn. The samples from fracture E (Figure 4c) are lower than the other fractures and do not show a clear trend. This can be explained by the origin of fracture $\mathrm{E}$ being somewhat distant from the ore deposit (Figure 2). The samples $38.7 \mathrm{~m}$ from the deposit in fracture E contain $12.6 \mathrm{ppm}$ and 14.8 ppm uranium, which are close to the host rock uranium concentration. Protactinium and radium concentrations in the surface fractures mirror the $U$ concentrations and also generally decrease with increasing distance away from the deposit (Table 2).

Results from the PB-1 core show uranium concentrations are lowest and least varied in the sample at $67 \mathrm{~m}$ (1032-1370 ppm) compared to the near-surface sample (2052-6628 ppm) and the deep sample (1870-7635 ppm) (Table 2). It can be seen that uranium concentration shows no trend with depth (Figure 5). The most concentrated (with respect to uranium) near-surface and deep sub-sample exceeds the typical uranium concentration of the ore deposit (range of 1000 to 33,000 ppm within areas of visible U mineralization, typical $=\sim 5000$ ppm; Pearcy et al. (1995)). The variation between the data points in Figure 5 is due to the different colored fractions representing different proportions of the identified minerals (see Appendix for the identified minerals). 
Thorium concentrations are much more uniform and range from 15-50 ppm Th for the surface fractures and 5-38 ppm Th for the drill core samples (Table 2). For the drill core, the highest concentration of $\sim 37 \mathrm{ppm}$ is found in a sub-sample of the near-surface sample, and there is an overall decrease in thorium concentrations with depth (Figure 5), which may be related to sample mineralogy. Th/U ratios are mostly dependent on the more variable $\mathrm{U}$ concentrations and range from 0.0029 to 3.4 for the surface fractures, and 0.001 to 0.017 for the drill core. The varying $\mathrm{Th} / \mathrm{U}$ ratios for the drill core sub-samples should enable us to construct ${ }^{238} \mathrm{U}_{-}^{234} \mathrm{U}_{-}{ }^{230} \mathrm{Th}_{-}-{ }^{232} \mathrm{Th}$ isochrons for each of the samples.

${ }^{234} \mathrm{U} /{ }^{238} \mathrm{U}$ activity ratios are generally higher than secular equilibrium for the surface fractures (1.05-1.49) (Table 3, Figure 6), although there are two exceptions to this ((NOPI-320 $=0.98$, NOPI-407 = 0.94). The drill core samples show a much wider range of ${ }^{234} \mathrm{U} /{ }^{238} \mathrm{U}$ disequilibrium, ranging from slight ${ }^{234} \mathrm{U}$ excess for the near-surface sample at $8.5 \mathrm{~m}(1.09-1.13)$, slight ${ }^{234} \mathrm{U}$ depletion for the deepest sample at $191 \mathrm{~m}$ (0.90-0.95), and a large range in ${ }^{234} \mathrm{U} /{ }^{238} \mathrm{U}$ disequilibrium for the intermediate depth sample (0.66-2.44) (Table 3, Figure 6). Hence, there does appear to be a range of ${ }^{234} \mathrm{U}_{-}^{238} \mathrm{U}$ open system behavior ranging from ${ }^{234} \mathrm{U}$ loss to ${ }^{234} \mathrm{U}$ gain, especially with depth. The powder and solution duplicate sample ${ }^{234} \mathrm{U} /{ }^{238} \mathrm{U}$ ratios are equivalent within estimated analytical uncertainty in all cases (Table 3).

It can be seen from Table 3 that ${ }^{230} \mathrm{Th} /{ }^{234} \mathrm{U}$ activity ratios are generally slightly above, but not within error of, secular equilibrium. Surface fracture samples have ${ }^{230} \mathrm{Th} /{ }^{234} \mathrm{U}$ activity ratios that generally range from 0.966 to 1.070 , with one anomalous sample (NOPI-320) at 0.568 . Drill core samples are also close to unity for the near-surface sample (1.017-1.029) and the sample at $67 \mathrm{~m}$ (0.969-1.015). ${ }^{230} \mathrm{Th} /{ }^{234} \mathrm{U}$ activity ratios for the deep sample are lower than unity (0.799-0.867).

${ }^{226} \mathrm{Ra} /{ }^{230} \mathrm{Th}$ activity ratios for the surface fractures range from 0.73 to 1.13 (Table 3 , Figure 7 ) but are generally within error or below the secular equilibrium value with one exception (NOPI425-2 at 1.13). ${ }^{231} \mathrm{~Pa} /{ }^{235} \mathrm{U}$ activity ratios for the surface fractures are generally within error of secular equilibrium (Table 3, Figure 8), with one exception (NOPI-320 at 0.64).

\section{Discussion}

\subsection{Radionuclide concentration}

All samples except NOPI-410 and NOPI-411 contain higher uranium concentrations than have previously been documented in the host tuff (cf. Leslie et al., 1993). The samples from fracture B in this study show a decrease in uranium concentration with distance from the ore deposit (Figure 4b) and corroborate previous radiometric measurements of samples from fracture B by Pearcy et al. (1995) and Prikryl et al. (1997). The relatively small number of samples analyzed from fractures $\mathrm{E}$ and $\mathrm{F}$ limit the conclusions that can be drawn for these fractures. However, Figure $4 \mathrm{a}$ shows that, in general, $\mathrm{U}$ concentration decreases with distance along the fracture (a proxy for 'horizontal' distance from the ore deposit at the surface). NOPI-410 and NOPI-411 (12.6-14.8 ppm U) at $38.7 \mathrm{~m}$ from the ore deposit along fracture E (Figure 4c) are within the range for the host tuff (Leslie et al., 1993) suggesting that uranium transport does not exceed 40 $\mathrm{m}$ in a northerly direction at the $+10 \mathrm{~m}$ level. Thorium concentrations show a relatively constant 
concentration along fractures at levels at or slightly higher than the host tuff (14-36 ppm, Leslie et al., 1993). These elevated concentrations are likely due to the original ore mineralization. ${ }^{231} \mathrm{~Pa}$ and ${ }^{226} \mathrm{Ra}$ concentrations, daughters of ${ }^{235} \mathrm{U}$ and ${ }^{238} \mathrm{U}$ respectively, show the same spatial distribution in the surface fractures as uranium.

The inverse relationship between uranium concentration and distance from the ore deposit is not observed in the vertical dimension. Uranium concentrations are lower at $67 \mathrm{~m}$ than at $8.5 \mathrm{~m}$ from the surface but increase again (in all sub-samples) at $191 \mathrm{~m}$ (Figure 5). The high uranium concentrations at $191 \mathrm{~m}$ suggests that uranium has been mobile over a much greater distance vertically than at the surface $(40 \mathrm{~m}$ in fracture $\mathrm{E}$, Figure $4 \mathrm{c})$. This may reflect a greater connectivity of fractures and/or the greater efficiency of transport through the downward flow of groundwater under gravity to the water table. The ore deposit does extend up to $100 \mathrm{~m}$ vertically adjacent to the drill core (Dobson et al., 2008), and the exact spatial extent of transport is thus uncertain. However, it is clear that there is some mechanism resulting in elevated uranium concentrations at approximately $190 \mathrm{~m}$, well below the known vertical extent of the ore deposit. Supporting evidence can be found in the presence of uraninite at $190 \mathrm{~m}$ (Fayek et al. (2006)) and peaks in the gamma $\log$ at around $190 \mathrm{~m}$ (Dobson et al., 2008). This transport is likely to have occurred through leaching of uranium during ore mineral alteration in oxidizing conditions (Calas et al., 2008). Goldstein et al. (2010) has shown that 93-97\% of the uranium is dissolved in the groundwater with the remainder attached to colloids.

Higher mobility of uranium relative to thorium can be explained by the greater solubility of uranium, compared to thorium, under oxidizing conditions. Under reducing conditions both $\mathrm{U}$ and $\mathrm{Th}$ are present in the +4 oxidation state. However, under oxidizing conditions, uranium is oxidized to the hexavalent state forming the soluble uranyl ion $\left(\mathrm{UO}_{2}{ }^{2+}\right)$. The uranyl ion can be transported in groundwater until either reducing conditions prevail or it can be fixed by sorption onto Fe-oxide minerals, manganese minerals, clay minerals and organic matter (e.g. Koppi et al., 1996; Chisholm-Brause et al., 2001; Duff et al., 2002; Chakraborty et al., 2010; Sachs and Bernhard, 2011; Li et al., 2014). Fayek et al. (2006) have dated secondary alteration minerals within the ore deposit that suggest oxidizing conditions were prevalent at $3.1 \mathrm{Ma}, 85 \mathrm{ka}$ and 45 ka. Reducing conditions were present at 1.6 Ma. These changing redox conditions are consistent with uranium mobility in the sub-surface and suggest discrete oxidizing conditions, with regard to uranium, resulting in times of high uranium mobility. The presence of goethite, hematite, kaolinite and quartz in these samples with calcite and dolomite also present in the $191 \mathrm{~m}$ samples (see Appendix) suggests that sorption to iron and clay minerals is an important uranium fixing process in this environment. No uranyl minerals were detected in these samples further supporting sorption rather than secondary mineral precipitation as the dominant uranium fixing mechanism (see further discussion in Section 5.2).

\subsection{U-Th disequilibria}

The majority (all but two) of the ${ }^{234} \mathrm{U} /{ }^{238} \mathrm{U}$ activity results for the surface fracture samples are $>1$ (above secular equilibrium, Table 3, Figure 6). This is consistent with ${ }^{234} \mathrm{U} /{ }^{238} \mathrm{U}$ isotope dilution/alpha spectrometry data presented by Prikryl et al. (1997) and demonstrates sorption from groundwater enriched in ${ }^{234} \mathrm{U}$ due to $\alpha$-recoil processes (e.g. Ivanovich et al., 1992 and references therein; Prikryl et al., 1997; Murrell et al., 2002). Our results show one sample from 
507 fracture $\mathrm{F}$ and one sample from fracture $\mathrm{E}$ have ${ }^{234} \mathrm{U} /{ }^{238} \mathrm{U}$ activity ratios $<1$, consistent with ${ }^{234} \mathrm{U}$ 508 loss due to alpha-recoil (e.g. Ivanovich et al., 1992 and references therein). Similar explanations 509 are attributed to the ${ }^{234} \mathrm{U} /{ }^{238} \mathrm{U}$ activity ratios for the sub-samples at $8.5 \mathrm{~m}$ and $191 \mathrm{~m}$ respectively. around unity, which reflects a more complex, multi-stage evolution consistent with interaction around unity, which reflects a more complex, multi-stage evolution consistent with interaction between groundwater enriched in ${ }^{234} \mathrm{U}$ and a tuff matrix depleted in ${ }^{234} \mathrm{U}$ due to recoil-related leaching. The ${ }^{234} \mathrm{U} /{ }^{238} \mathrm{U} v s$. ${ }^{238} \mathrm{U}$ systematics for this sample lie on a mixing curve and closely resembles a trend that one might expect for modern water samples (Goldstein et al., 2010). This suggests open system behavior for $U$ for this sample. A single $U$ deposition event would probably result in constant ${ }^{234} \mathrm{U} /{ }^{238} \mathrm{U}$ values, thus the variable ${ }^{234} \mathrm{U} /{ }^{238} \mathrm{U}$ activity ratios with distance along the fractures imply a mobilization process that had multiple stages (Prikryl et al., 1997). Hence, our results are consistent with the model of discrete oxidizing conditions resulting in times of high uranium mobility described in Section 5.1.

Further constraints on ${ }^{234} \mathrm{U} /{ }^{238} \mathrm{U}$ evolution can be obtained from a plot of ${ }^{234} \mathrm{U} /{ }^{238} \mathrm{U} v s .{ }^{230} \mathrm{Th} /{ }^{234} \mathrm{U}$ activity ratios for the surface fracture and drill core samples (Figure 9). The majority of the samples have measured $\left({ }^{234} \mathrm{U}\right) /\left({ }^{238} \mathrm{U}\right)$ ratios between 1 and 2 , and lie close to the lines of evolution expected if initial $\left.\left({ }^{234} \mathrm{U}\right) /{ }^{238} \mathrm{U}\right)$ ratios were between 1 and 2. Sample PB1023849 at 67 $\mathrm{m}$ is distinctive in that many of the sub-samples have measured $\left({ }^{234} \mathrm{U}\right) /\left({ }^{238} \mathrm{U}\right)$ ratios less than the expected initial $\left({ }^{234} U\right) /\left({ }^{238} U\right)$ ratio. This suggests open system behavior for this sample. Closed system ${ }^{238} \mathrm{U}_{-}{ }^{234} \mathrm{U}_{-}{ }^{230} \mathrm{Th}$ model ages assuming no initial Th and pure ingrowth of daughter isotopes into the parent are also shown in Figure 9 and Table 4. These assumptions are most closely followed for samples with high $U$ concentration, where a vast majority of the ${ }^{230} \mathrm{Th}$ present in the samples is from ${ }^{234} \mathrm{U}$ decay. However, in general these model ages will be approximations to the true age since $U$ was mobile in the fractures. It can be seen from Figure 9 and Table 4 that these model ages are generally $>313 \mathrm{ka}$ for the surface fractures and $>183 \mathrm{ka}$ for the drill core. Exceptions to this recent closed system behavior are sample NOPI-320 (92 ka, fracture F), NOPI-403 (fracture E), NOPI-407 (fracture E) and PB1023849-3 (67 m depth). The latter three are all in the forbidden zone of Figure 9. This zone represents samples that have activity ratios that cannot be attributed to a single U-distribution event but instead represent a more complex U mobilization history (Thiel et al., 1983). For these few samples, recent open system $U$ behavior is suggested. For the other samples we also attribute multi-stage fracture flow behavior (due to the variable $U$ activity ratios) but these do not plot in the forbidden zone, implying $\mathrm{U}$ mobility in the more distant past. ${ }^{238} \mathrm{U}_{-}{ }^{234} \mathrm{U}_{-}{ }^{230} \mathrm{Th}$ model ages from fractures $\mathrm{E}$ and $\mathrm{F}$ appear to yield some younger ages (forbidden zone-613 ka and 92-316 ka respectively) than fractures B and C (314-538 ka and $531 \mathrm{ka}$ respectively) (Table 4). This strongly suggests that the geochemical conditions in the fractures vary around the deposit.

Data for the majority of these samples imply that environmental conditions have been unfavorable for U-Th mobility for the last $\sim 183-530 \mathrm{ka}$. The iron minerals present (the $\mathrm{Fe}^{3+}$ oxides, goethite and hematite) suggest prevailing oxidizing conditions although it has been shown that these can be preserved below the redox front where reducing conditions prevail (Drake, 2009). However the formation of schoepite and weeksite/boltwoodite in the ore deposit in the most recent $100 \mathrm{ka}$ (Fayek et al., 2006) suggests recent oxidizing conditions. Cerium anomalies presented by Calas et al. (2008) also indicate widespread oxidizing conditions surrounding the deposit. Therefore we favor irreversible sorption onto solid materials (primarily 
Fe-oxide or clay minerals) as the $\mathrm{U}$ and Th fixing mechanism (e.g. Missana et al., 2004; Tinnacher et al., 2011 and references therein; Yusan and Erenturk, 2011). The irreversible sorption would then lead to incorporation of $U$ and $T h$ within the mineral structures. Ingrowth of ${ }^{230}$ Th into ${ }^{234} \mathrm{U}$ would then occur with subsequent closed system $\mathrm{U}$ and $\mathrm{Th}$ behavior.

Additional constraints on the timing of $U$ and Th mobility can also be derived from ${ }^{238} \mathrm{U}_{-}{ }^{234} \mathrm{U}_{-}$ ${ }^{230} \mathrm{Th}-{ }^{232} \mathrm{Th}$ isochrons. As discussed earlier, we intended to use the variable U/Th ratio in the drill core sub-samples to construct U-Th isochrons. However, the resulting isochrons (Figure 10) have MSWD (mean square weighted deviation - a measure of the goodness of fit accounting for the relative importance of both internal and external reproducibility) values $>1$ and range from 9 to 239. This shows that the data are over-dispersed, which is most likely due to the failure of one or more assumptions inherent in the isochrons. One assumption is that the sub-samples formed at exactly the same time with the same initial ${ }^{234} \mathrm{U} /{ }^{238} \mathrm{U}$ and ${ }^{230} \mathrm{Th} /{ }^{232} \mathrm{Th}$ isotopic ratios. However, we expect that the fracture-fill material sub-samples, which consist of different proportions of the minerals listed in the Appendix, were probably closed to U-Th mobility at different times and had different initial $U$ and Th isotopic ratios. Because the isochron MSWD values are greater than one we instead refer to these relationships as linear age trends (Figure 10).

From these linear age trends, it is possible to calculate the time at which the fractures became closed to U-Th mobility. To the best of our knowledge, this is the first attempt at this type of dating of samples from Peña Blanca. The $\left({ }^{234} \mathrm{U}\right) /\left({ }^{232} \mathrm{Th}\right) v s .\left({ }^{238} \mathrm{U}\right) /\left({ }^{232} \mathrm{Th}\right)$ linear trend cannot be drawn for the sample at $67 \mathrm{~m}$, indicating open system behavior for this sample. This observation is consistent with the presence of PB1023849-3-pd1 and -pd2 in the forbidden zone (Table 4, Figure 9) and the variable ${ }^{234} U /{ }^{238} U$ activity ratios for this sample (Figure 6, Table 2). The presence of an apparent linear trend for ${ }^{230} \mathrm{Th} /{ }^{232} \mathrm{Th} v s .{ }^{234} \mathrm{U} /{ }^{232} \mathrm{Th}$ (Figure 10b) for the $67 \mathrm{~m}$ sample does suggest that the ${ }^{230} \mathrm{Th}$ has grown into the ${ }^{234} \mathrm{U}$, and that $\mathrm{Th}$ has been relatively undisturbed despite the $U$ open system behavior. For the samples at $8.5 \mathrm{~m}$ and $191 \mathrm{~m}$ there is a wide range in U/Th ratios for the sub-samples yielding well-defined U-Th linear age trends, with ages of $440 \pm 30 \mathrm{ka}(2 \sigma)$ and $210 \pm 20 \mathrm{ka}$ respectively. Despite these linear age trends not being isochrons by exact definition, the sub-samples are equivalent in age within the uncertainties quoted, which although significant are small relative to the determined ages. Hence, valuable age information has been obtained for these samples using the isochron method. As stated above, these ages are interpreted as the time after which the fracture samples behaved as a closed system for both $U$ and Th. This is true despite ongoing fluid flow of $U$ and Th in the fractures in the more recent past $(<8 \mathrm{ka})$ as indicated by the observed ${ }^{230} \mathrm{Th}^{2}{ }^{226} \mathrm{Ra}$ disequilibria (see Section 5.3 below). These linear trend ages are also broadly consistent with the ${ }^{230} \mathrm{Th}-{ }^{234} \mathrm{U}-$ ${ }^{238} \mathrm{U}$ model ages (Table 4), supporting the assumption that little initial ${ }^{230} \mathrm{Th}$ daughter was present compared to that which grew into the parent ${ }^{234} \mathrm{U}$.

\subsection{Th-Ra and U-Pa disequilibria}

${ }^{226} \mathrm{Ra} /{ }^{230} \mathrm{Th}$ activity ratios for the surface fractures range from $\sim 0.7$ to 1.2 , but most samples have activity ratios $<1$ (Figure 7). This indicates radium loss and mobility due to recent ( $<8 \mathrm{ka}$ ) mineral-water interaction in the fractures. This evidence for $\mathrm{Ra}$ mobility agrees with prior vegetation (Leslie et al., 1999) and unsaturated zone (UZ) groundwater studies (Goldstein et al., 2010) indicating high Ra mobility in the UZ near the deposit. These data suggest recent 
environmental conditions where complexing with chloride is favored over complexing with sulfate (Cowart and Burnett, 1994 and references therein).

To further investigate the timing of Ra mobility, we have used gamma counting techniques to measure disequilibria of short-lived daughter nuclides $\left({ }^{226} \mathrm{Ra}-{ }^{210} \mathrm{~Pb},{ }^{226} \mathrm{Ra}-{ }^{222} \mathrm{Rn}\right.$, and $\left.{ }^{238} \mathrm{U}-{ }^{234} \mathrm{Th}\right)$ for some of the samples. Although there are relatively large errors for gamma counting of the low energy $(46 \mathrm{keV}){ }^{210} \mathrm{~Pb}$ gamma emission, we have found no evidence for disequilibria between ${ }^{226} \mathrm{Ra}^{-}{ }^{210} \mathrm{~Pb},{ }^{226} \mathrm{Ra}^{2}{ }^{22} \mathrm{Rn}$, or ${ }^{238} \mathrm{U}^{234} \mathrm{Th}$. This indicates closed system $\mathrm{Ra}$ and $\mathrm{Pb}$ behavior for the past five ${ }^{210} \mathrm{~Pb}$ half-lives $(\sim 100$ a) in the fractures.

In general, all of the surface fracture samples have ${ }^{231} \mathrm{~Pa} /{ }^{235} \mathrm{U}$ activity ratios within error of secular equilibrium, with only one exception (Figure 8). Hence, closed system ${ }^{235} \mathrm{U}_{-}{ }^{231} \mathrm{~Pa}$ model ages are generally $>185 \mathrm{ka}$, with the singular exception (NOPI-320 at $49 \mathrm{ka}$ ) (Table 2), and are generally inconsistent with open system models for $\mathrm{U}$ and $\mathrm{Pa}$ over this time period (e.g. Dequincey et al., 2002; Paces et al., 2013). These data suggest that local conditions favour Pa to be in its most stable +5 state as $\mathrm{PaO}^{3+}$. In this state $\mathrm{Pa}$ shows a strong tendency towards hydrolysis as well as sorption onto solid surfaces (Natrajan et al., 2014). Irreversible sorption onto solid surfaces is also invoked as a likely cause of U-Th immobility over the last 183+ ka (Section 5.2). Sample NOPI-320 (fracture F) has anomalously low ${ }^{230} \mathrm{Th} /{ }^{234} \mathrm{U}$ and ${ }^{231} \mathrm{~Pa} /{ }^{235} \mathrm{U}$ activity ratios, resulting in the younger model ages. This may be due to open system behavior, namely ${ }^{230} \mathrm{Th}$ and ${ }^{231} \mathrm{~Pa}$ loss, for this single sample.

\subsection{Open vs. closed system models for actinide transport at Peña Blanca}

Various timespans of radionuclide mobility at Peña Blanca are summarized in Figure 11. Uranium has been mobile up to $200 \mathrm{~m}$ vertically and $40 \mathrm{~m}$ horizontally in the recent history of the deposit (1.2 to 0.2 Ma). Fractures have been shown to be effective conduits for this transport. In the most recent $0.2 \mathrm{Ma}$, uranium appears to have been mostly immobile with some evidence of $U$ mobility in a few locations depending on the sample and sample location. This is in contrast to previous studies that show evidence for U mobility at Peña Blanca in the last $100 \mathrm{ka}$ (e.g. Pearcy et al., 1995; Murphy, 2000; Fayek et al., 2006). Whilst our results do corroborate these studies in a few locations the majority of our samples show closed system behavior with respect to $\mathrm{U}$ and $\mathrm{Th}$ in the most recent past. In almost all cases the Th-Pa radionuclides studied here have been immobile for the past $200 \mathrm{ka}$. Radium appears to have been recently $(0.1-8 \mathrm{ka})$ mobile. The results from the surface fractures are consistent with, and extend the findings of, previous radiometric studies (e.g. Pearcy et al., 1995; Prikryl et al., 1997). Our results from the drill core show a more complex series of mineral-water interactions and uranium sorption and provide new U-series information about radionuclide transport through the fractures below the surface. At all three depths the fractures have been shown to have been open, and conduits for $U$ mobility, in the last 1.2 Ma. The construction of ${ }^{238} \mathrm{U}_{-}{ }^{234} \mathrm{U}-{ }^{230} \mathrm{Th}-{ }^{232} \mathrm{Th}$ linear age trends show a complex picture of the fractures being closed to $U$ and Th mobility at some depths for the last 210 and $440 \mathrm{ka}$ and recently open to $U$ at an intermediate depth. These three sample points show unexpected complexity in the geochemical system and warrant further investigation. 
Suggested causes of the open system behavior for $\mathrm{Ra}$ and $\mathrm{U}$ in the past are mineral-water interaction and changes in oxidation state for $\mathrm{U}$, which appears to be sample dependent. Fayek et al. (2006) dated the formation of several minerals within the ore deposit (uranophane at $3.1 \pm 0.5$ $\mathrm{Ma}$, colloform uraninite at $1.6 \pm 0.5 \mathrm{Ma}$, schoepite/dehydrated schoepite at $85 \pm 8 \mathrm{ka}$, and weeksite/boltwoodite at $41 \pm 5 \mathrm{ka}$, Figure 11). These results suggest changing redox conditions within the ore deposit over the last $\sim 3$ million years. The variable ${ }^{234} \mathrm{U} /{ }^{238} \mathrm{U}$ activity ratios are consistent with a number of oxidation 'events' occurring during this time, mobilizing uranium and resulting in the spatial distribution shown in our results. Once uranium became mobilized it was fixed, most likely by irreversible sorption, onto the iron oxides (e.g. goethite and hematite) and clay minerals (e.g. kaolinite) identified previously (e.g. Prikryl et al., 1997; Dobson et al., 2008) and in these samples. Whilst Schindler et al. (2010) showed association between uranium and opal at Peña Blanca, the results of XRD analysis on these samples do not show the presence of opal or uranyl minerals. Therefore, we consider sorption to clays and iron minerals to be the main mechanism of uranium fixation. The recent mobility of radium suggests a vadose environment with elevated chloride. The broad immobility of $\mathrm{Th}$ and $\mathrm{Pa}$ is consistent with irreversible sorption onto $\mathrm{Fe}$ and clay minerals over the most recent $185 \mathrm{ka}$. The reasons why a few of the samples show recent $(<200 \mathrm{ka})$ open system $U$ behavior are currently unknown, but may relate to sample mineralogy and U concentrations. More detailed high-resolution chemical, mineralogical, and isotopic studies should help provide a much more complete understanding of the specific processes causing the variable open $v$ s. closed system behavior for $U$.

Our results also allow us to make some general observations about the potential geochemical mobility of many radionuclides in spent fuel from a waste repository in fractured, unsaturated tuff. The mainly closed system behavior for Th-Pa over the past $\sim 200$ ka provides evidence of the lack of geochemical mobility for some actinide radionuclides ( $\mathrm{Th}, \mathrm{Pa}$ and by analogy $\mathrm{Pu}, \mathrm{Am}$ and lanthanides) in spent fuel in this type of environment over time-scales of $10^{4}-10^{5}$ years. As discussed above, the situation for uranium is more complex, with both closed and open system behavior observed depending on sample and timescale. However, most of the samples exhibit closed system $U$ behavior over the past $200 \mathrm{ka}$, and thus it appears that $U$ would be mostly immobile for a waste repository in this environment over this timescale. The observation of Ra mobility suggests that other chemically similar fission product radionuclides present in spent fuel, such as divalent ${ }^{90} \mathrm{Sr}$ and ${ }^{133} \mathrm{Ba}$, and monovalent ${ }^{137} \mathrm{Cs}$, may be more mobile. However, these fission product radionuclides have much shorter half-lives than actinides and would likely decay substantially before geochemical transport from a waste repository could occur. ${ }^{99} \mathrm{Tc}$ and ${ }^{129} \mathrm{I}$ are more problematic due to their longer half-lives ( $\sim 200 \mathrm{ka}$ and $\sim 15.7 \mathrm{Ma}$ respectively) and behavior as anions. The extent of their geochemical transport from a waste repository in this environment is subject to further research.

\section{Conclusions}

We have presented precise mass spectrometric uranium-series concentration and isotopic ratios in three dimensions for fracture-fill materials at the Peña Blanca Nopal I ore deposit. U-Th-Pa model ages have been calculated from the isotopic data and ${ }^{238} \mathrm{U}_{-}{ }^{234} \mathrm{U}_{-}{ }^{230} \mathrm{Th}^{-232} \mathrm{Th}$ linear age trends have been generated for a number of samples allowing ages of fracture closure to actinide mobility to be calculated. In summary, we conclude: 
1) Uranium has been found to be mobile within the fractures up to $40 \mathrm{~m}$ horizontally and up to $200 \mathrm{~m}$ below the surface at Peña Blanca. Uranium concentrations below the surface can be very high exceeding the typical uranium concentration of the ore deposit.

2) The concentration of uranium in the sampled fracture-fill materials decreases with distance from the ore deposit in the horizontal dimension but shows no trend with depth.

3) U-Th-Ra-Pa disequilibria and model ages indicate (i) wide-spread U mobility between $0.2 \mathrm{Ma}$ and 1.2 Ma, (ii) some $U$ mobility but mostly $U$ immobility in the last $0.2 \mathrm{Ma}$, (iii) Ra mobility in the last $0.1-8 \mathrm{ka}$, and (iv) Th-Pa immobility in the last $185 \mathrm{ka}$.

4) ${ }^{238} \mathrm{U}_{-}{ }^{234} \mathrm{U}_{-}{ }^{230} \mathrm{Th}^{2}{ }^{232} \mathrm{Th}$ linear age trend calculations show that fractures sampled at $8.5 \mathrm{~m}$ and $191 \mathrm{~m}$ were closed to U-Th mobility at $440 \pm 30 \mathrm{ka}$ and $210 \pm 20 \mathrm{ka}$ respectively. The fracture sub-samples at $67 \mathrm{~m}$ are exceptional in that they do not form a linear age trend and have recently been an open system for $\mathrm{U}$.

This study yields important findings for the siting of a high level radioactive waste repository on a site of fractured, unsaturated tuff. The mainly closed system behavior of Th-Pa over the past $200 \mathrm{ka}$ provides evidence of the immobility of these elements (and by analogy $\mathrm{Pu}, \mathrm{Am}$ and lanthanides). However, the recent mobility of Ra suggests that spent fuel radionuclides such as divalent ${ }^{90} \mathrm{Sr}$ and ${ }^{133} \mathrm{Ba}$ and monovalent ${ }^{137} \mathrm{Cs}$ may be more mobile. The unexpected complexity in uranium mobility as a function of sample and timescale would require additional study in identifying the controls for this variable behavior. This study also indicates that there are differences in the extent of uranium mobility between individual fractures. Therefore, potential differences in the spatial mobility of uranium should be considered when evaluating possible repository sites or contaminant transport from uranium ore deposits.

\section{Acknowledgements}

Research on surface fractures was supported by the U.S. DOE, Office of Civilian Radioactive Waste Management (OCRWM), under contract DE-AC02-05CH11231 to Los Alamos National Laboratory. Research on deep fractures was supported by Office of Science, Basic Energy Sciences, Chemical Sciences, Geosciences and Biosciences Division of the U.S. Department of Energy under Contract No. 2013LANLE3CC to Los Alamos National Laboratory. The views expressed in this article are those of the authors and do not necessarily reflect the views or policies of the United States Department of Energy. We thank Don Dry at LANL for assistance with gamma counting measurements and Eugene Ilton at PNNL and EMSL for assistance with XRD analysis. We thank the two anonymous journal reviewers for their helpful comments.

\section{References}

Akovali, Y.A. (1996). Nuclear data sheets for A=226*. Nuclear Data Sheets, 77, 433. 
Alba, L.A., Chavez, R. (1974). K-Ar ages from volcanic rocks from the Central Peña Blanca, Chihuahua, Mexico. Isochron/West, 10, 21-23.

Audi, G., Kondev, F.G., Wang, M., Pfeiffer, B., Sun, X., Blachot, J., MacCormick, M. (2012).

Benson, A., Kinsley, L., Willmes, M., Defleur, A., Kokkonen, H., Mussi, M., Grün, R. (2013). Laser ablation depth profiling of U-series and $\mathrm{Sr}$ isotopes in human fossils. J. Archaeolog. Sci., 40 (7), 2991-3000.

Calas, G. (1977). Les phénomènes d'altération hydrothermale et leur relation avec les minéralisations uranifères en milieu volcanique: Le cas des ignimbrites tertiares de la Sierra de Peña Blanca, Chihuahua, Mexico. Sci. Géol. Bull., 30, 3-18.

Calas, G., Agrinier, P., Allard, T., Ildefonse, P. (2008). Alteration geochemistry of the Nopal I uranium deposit (Sierra Peña Blanca, Mexico), a natural analogue for a radioactive waste repository in volcanic tuffs. Terra Nova, 20(3), 206-212.

Chakraborty, S., Favre, F., Banerjee, D., Scheinost, A.C., Nullet, M., Ehrhardt, J.-J., Brendle, J., Vidal, L., Charlet, L. (2010). U(VI) Sorption and Reduction by Fe(II) Sorbed on Montmorillonite. Environ. Sci. Technol., 44, 3779-3785.

Cheng, H., Edwards, R.L., Hoff, J., Gallup, C.D., Richards, D.A., Asmerom, Y. (2000). The half-lives of U-234 and Th-230. Chem. Geol., 169, 17-33.

Chisholm-Brause, C.J., Berg, J.M., Matzner, R.A., Morris, D.E. (2001). Uranium (VI) Sorption Complexes on Montmorillonite as a Function of Solution Chemistry. J. of Colloid Interface Sci., 233, 38-49.

Cooper, K.M., Goldstein, S.J., Sims, K.W.W., Murrell, M.T. (2003). Uranium-series chronology of Gorda Ridge volcanism: new evidence from the 1996 eruption. Earth Planet. Sci. Lett., 206, 459-475.

Cowart, J.B., Burnett, W.C. (1994). The Distribution of Uranium and Thorium Decay-Series Radionuclides in the Environment - A Review. J. Environ. Qual., 23, 651-662.

Dawood, Y.H. (2001). Uranium-series disequilibrium dating of secondary uranium ore from the south Eastern Desert of Egypt. Appl. Rad. Isot., 55, 881-887.

De Paolo, D.J., Maher, K., Christensen, J.N., McManus, J. (2006). Sediment transport time measured with U-series isotopes: Results from ODP North Atlantic drift site 984. Earth Planet. Sci. Lett., 248, 394-410.

Denton, J.S., Murrell, M.T., Goldstein, S.J., Nunn, A.J., Amato, R.S., Hinrichs, K.A. (2013). Evaluation of new geological reference materials for uranium-series measurements: CGSG glasses and macusanite obsidian. Anal. Chem., 85, 9975-9981. 
Dequincey, O., Chabaux, F., Clauer, N., Sigmarsson, O., Leiwig, N., Leprun, J.-C. (2002).

Chemical mobilizations in laterites: evidence from trace elements and ${ }^{238} \mathrm{U}_{-}{ }^{234} \mathrm{U}_{-}{ }^{230} \mathrm{Th}$ disequilibria. Geochim. Cosmochim. Acta, 66, 1197-1210.

Dobson, P.F., Fayek, M., Goodell, P.C., Ghezzehei, T.A., Melchor, F., Murrell, M.T., Oliver, R., Reyes-Cortés, I.A., de la Garza, R., Simmons, A. (2008). Stratigraphy of the PB-1 well, Nopal I uranium deposit, Sierra Peña Blanca, Chihuahua, Mexico. Int. Geol. Rev., 50, 959-974.

Dobson, P.F., Ghezzehei, T.A., Cook, P.J., Rodríguez-Pineda, J.A., Villalba, L., De la Garza, R. (2012). Heterogeneous seepage at the Nopal I natural analogue site, Chihuahua, Mexico. Hydrogeol. J., 20, 155-166.

Drake, H., Tullborg, E.-L., MacKenzie, A.B. (2009). Detecting the near-surface redox front in crystalline bedrock using fracture mineral distribution, geochemistry and U-series disequilibrium. Appl. Geochem., 24, 1023-1039.

Duff, M.C., Hunter, D.B., Bertsch, P.M., Amrhein, C. (1999). Factors influencing uranium reduction and solubility in evaporation pond sediments. Biogeochemistry, 45, 95-114.

Duff, M.C., Coughlin, J.U., Hunter, D.B. (2002). Uranium co-precipitation with iron oxide minerals. Geochim. Cosmochim. Acta, 66, 3533-3547.

Eggins, S.M., Grün, R., McCulloch, M.T., Pike, A.W.G., Chappell, J., Kinsley, L., Mortimer, G., Shelley, M., Colin, V., Murray-Wallace, C.V., Spötl, C.C., Taylor, L.L. (2005). In situ U-series dating by laser-ablation multi-collector ICPMS: New prospects for quaternary geochronology. Quat. Sci. Rev., 24, 2523-2538.

Fayek, M., Ren, M., Goodell, P., Dobson, P., Saucedo, A., Kelts, A., Utsunomiya, S., Ewing, R.C., Riciputi, L.R., Reyes, I. (2006). Paragenesis and Geochronology of the Nopal I Uranium Deposit, Mexico, in Proceedings, 2006 International High Level Radioactive Waste Management Conference, Las Vegas, NV, American Nuclear Society, pp. 55-62.

Finch, R.J., Ewing, R.C. (1989). Alteration of natural $\mathrm{UO}_{2}$ under oxidizing conditions from Shinkolobwe, Katanga, Zaire: a natural analogue for the corrosion of spent fuel. Technical report 89-37. Swedish Nuclear Fuel and Waste Management Company (SKB), Stockholm.

Gabriel, U., Gaudet, J.P., Spadini, L., Charlet, L. (1998). Reactive transport of uranyl in a goethite column: An experimental and modelling study. Chem. Geol., 151, 107-128.

Gascoyne, M., Miller, N.H., Neymark, L.A. (2002). Uranium-series disequilibrium in tuffs from Yucca Mountain, Nevada, as evidence of pore-fluid flow over the last million years. Appl. Geochem., 17, 781-792.

Gavrilescu, M., Pavel, L.V., Cretescu, I. (2009). Characterization and remediation of soils contaminated with uranium. J. Hazard. Mater., 163, 475-510. 
George-Aniel, B., Leroy, J., Poty, B. (1985). Uranium Deposits of the Sierra Peña Blanca, in Uranium Deposits in Volcanic Rocks, Proceedings of a Technical Committee Meeting on Uranium Deposits in Volcanic Rocks, El Paso, Texas. IAEA, pp. 175-186.

George-Aniel, B., Leroy, J.L., Poty, B. (1991). Volcanogenic uranium mineralizations in the Sierra Peña Blanca district, Chihuahua, Mexico: Three genetic models. Econ. Geol., 86, 233-248.

Ghezzehei, T.A., Dobson, P.F., Rodriguez, J.A., Cook, P.J. (2006). Infiltration and Seepage through Fractured Welded Tuff, in Proceedings of the 11th International High-Level Radioactive Waste Management Conference, Las Vegas, Nevada, American Nuclear Society, Illinois, pp. $105-110$.

Goldstein, S.J., Murrell, M.T., Janecky, D.R. (1989). Th and U isotopic systematics of basalts from the Juan de Fuca and Gorda Ridges by mass spectrometry. Earth Planet. Sci. Lett., 96, 134146.

Goldstein, S.J., Stirling, C.H. (2003). Techniques for Measuring Uranium-series Nuclides, 19922002. In Bourdon, B., Henderson, C.C., Lundstrom, C.C., Turner, S.P (Eds), Rev. Mineral. Geochem., 52, pp. 23-57.

Goldstein, S.J., Abdel-Fattah, A.I., Murrell, M.T., Dobson, P.F., Norman, D.E., Amato, R.S., Nunn, A.J. (2010). Uranium-Series Constraints on Radionuclide Transport and Groundwater Flow at the Nopal I Uranium Deposit, Sierra Peña Blanca, Mexico. Environ. Sci. Tech., 44, 1579-1586.

Goodell, P.C. (1981). Geology of the Peña Blanca uranium deposits, Chihuahua, Mexico, in Goodell, P.C., Waters, A.C. (Eds), Uranium in Volcanic and Volcaniclastic Rocks, AAPG Stud. Geol., 13, pp. 275-291.

Goodell, P.C. (1985). Chihuahua City Uranium Province, Chihuahua, Mexico, in Uranium Deposits in Volcanic Rocks, Proceedings of a Technical Committee Meeting on Uranium Deposits in Volcanic Rocks, IAEA, Vienna, Austria, pp. 97-124.

Guillaumont, R., Ionova, G., Krupa, J.C., David, F. (1996). Consideration on Protactinium Redox Potentials. Radiochim. Acta, 75, 97-103.

Ho, C.J., Miller, N.H. (1985). Effect of humic acid on uranium uptake by hematite particles. J. Colloid Interface Sci., 106, 281-288.

Ho, C.J., Miller, N.H. (1986). Adsorption of uranyl species from bicarbonate solution onto hematite particles. J. Colloid Interfacial Sci., 110, 165-171.

Ingles, J.C., Sutarno, R., Bowman, W.S., Faye, G.H. (1977). Radioactive ores DH-1, DL-1, BL1, BL-2, BL-3, and BL-4 - Certified Reference Materials. Canmet Report 77-64, Energy, Mines and Resources Canada (Ottawa, CA), pp. 22. 
Ivanovich, M., Latham, A.G., Longworth, G., Gascoyne, M. (1992). Applications to Radioactive Waste Disposal Studies, in Ivanovich, M, Harmon, R.S. (Eds), Uranium-Series Disequilibrium: Applications to Earth, Marine and Environmental Sciences, Oxford Science Publications, Oxford. pp. 583-630.

Jaffey, A.H., Flynn, K.F., Glendenin, L.E., Bently, W.C., Essling, A.M. (1971). Precision measurements of half-lives and specific activities of ${ }^{235} \mathrm{U}$ and ${ }^{238} \mathrm{U}$. Phys. Rev., 4, 1889.

882

Janeczek, J., Ewing, R.C. (1992). Coffinitization - a mechanism for the alteration of spent fuel

Kaufman, A., Ku, T.-L., Luo, S. (1995). Uranium-series dating of carnotites: concordance between ${ }^{230}$ Th and ${ }^{231} \mathrm{~Pa}$ ages. Chem, Geol. Isot. Geosci., 120, 175-181.

Kigoshi, K. (1971). Alpha-Recoil Thorium-234: Dissolution into Water and the Uranium234/Uranium-238 Disequilibrium in Nature. Science, 73, 47-48.

Koppi, A.J., Edis, R., Field, D.J., Geering, H.R., Klessa, D.A., Cockayne, D.J.H. (1996). Rare earth element trends and cerium-uranium-manganese associations in weathered rock from Koongarra, Northern Territory, Australia. Geochim. Cosmochim. Acta, 60(10), 1695-1707.

Krishnaswami, S., Graustein, W.C., Turekian, K.K., Dowd, F. (1982). Radium, thorium, and radioactive lead isotopes in groundwaters: application to the in situ determination of adsorptiondesorption rate constants and retardation factors. Water Resor. Res., 6, 1663-1675.

Ku, T.L., Luo, S., Goldstein, S.J., Murrell, M.T., Chu, W.L., Dobson, P.F. (2009). Modeling non-steady state radioisotope transport in the vadose zone - A case study using uranium isotopes at Peña Blanca, Mexico. Geochim. Cosmochim. Acta, 73, 6052-6064.

Langmuir, D. (1978). Uranium Solution-Mineral Equilibria at Low Temperatures with Application to Sedimentary Ore Deposits. Geochim. Cosmochim. Acta, 42, 547-569.

Langmuir, D., Herman, J.S. (1980). The mobility of thorium in natural waters at low temperatures. Geochim. Cosmochim. Acta, 44, 1753-1766.

Layne, G.D., Sims, K.W.W. (2000). Analysis of ${ }^{232} \mathrm{Th} /{ }^{230} \mathrm{Th}$ in volcanic rocks by Secondary Ionization Mass Spectrometry. Int. J. Mass Spectrom., 203 (1-3), 187-198.

Leslie, B.W., Pearcy, E.C., Prikryl, J.D. (1993). Oxidative alteration or uraninite under hydrologically unsaturated conditions at Peña Blanca, Chihuahua, Mexico: contaminant transport and source term constraints for the proposed repository at Yucca Mountain, Nevada, in: Interrante, C., Pabalan, R. (Eds), Scientific Basis for Nuclear Waste Management XVI, Materials Research Society, Boston, Massachusetts, pp. 505-512. 
Leslie, B.W., Pickett, D.A., Pearcy, E. (1999). Vegetation-derived insights on the mobilization and potential transport of radionuclides from the NOPAL 1 natural analog site, Mexico. Material Research Society Symposium Proceedings, 555, pp. 833-842.

Li, D., Seaman, J.C., Chang, H.-S., Jaffe, P.R., Koster van Groos, P., Jiang, D.-T., Chen, N., Lin, J., Arthur, Z., Pan, Y., Scheckel, K.G., Newville, M., Lanzirotti, A., Kaplan, D.I. (2014). Retention and chemical speciation of uranium in an oxidized wetland sediment from the Savannah River Site. J. Environ. Radioact., 131, 40-46.

Lienert, C., Short, S.A., von Gunten, H.R. (1994). Uranium infiltration from a river to shallow groundwater. Geochim. Cosmochim. Acta, 58, 5455-5464.

Lloyd, J.R., Renshaw, J.C. (2005). Bioremediation of radioactive waste: radionuclide-microbe interactions in laboratory and field-scale studies. Curr. Opin. Biotechnol., 16, 254-260.

MacKenzie, A.B., Scott, R.D., Linsalata, P., Miekeley, N. (1992). Natural decay series studies of the redox front system in the Poços de Caldas uranium mineralization. J Geochem. Expl., 45, 289-322.

McDowell, F. (2007). Timing of Intense Magmatic Episodes in the Northern Sierra Madre Occidental, Mexico. Geol. Soc. Am. Abstr., 39(6), 391.

McDowell, F., Mauger, R. (1994). K-Ar and U-Pb zircon chronology of Late Cretaceous and Tertiary magmatism in central Chihuahua State, Mexico. Geol. Soc. Am. Bull., 106, 118-132.

Merroun, M.L., Selenska-Pobell, S. (2008). Bacterial interactions with uranium: An environmental perspective. J. Contam. Hydrol., 102, 285-295.

Mertz-Kraus, R., Jochum, K.P., Sharp, W.D., Stoll, B., Weis, U., Andreae, M.O. (2010). In situ ${ }^{230} \mathrm{Th}-{ }^{232} \mathrm{Th}-{ }^{234} \mathrm{U}-{ }^{238} \mathrm{U}$ analysis of silicate glasses and carbonates using laser ablation single collector sector-field ICP-MS. J. Anal. At. Spectrom., 25 (12), 1895-1904.

Missana, T., García-Gutiérrez, M., Alonso, Ú. (2004). Kinetics and irreversibility of cesium and uranium sorption onto bentonite colloids in a deep granitic environment. Appl. Clay Sci., 26, 137-150.

Montúfar, J.C.B., Cortés, M.R., Cortés, I.A.R., Valdez, M.S.E., de la Garza, O.C.H., Ronquillo, D.P.N., Peraza, E.H., Villalobos, M.R., Cabrera, M.E.M. (2012). Uranium-series isotopes transport in surface, vadose and ground waters at San Marcos uranium bearing basin, Chihuahua, Mexico. Appl. Geochem., 27, 1111-1122.

Morse, J.W., Choppin, G.R. (1991). The chemistry of transuranic elements in natural waters. Rev. Aquatic Sci., 4, 1-22.

Murphy, W.M., Pearcy, E.C., Pickett, D.A. (1997). Radionuclide transport from mined uranium ore at Peña Blanca, Mexico, in Balkema, A.A. (Ed), Tailings and Mine Waste '97, Proceedings 21 
of the $4^{\text {th }}$ International Conference on Tailings and Mine Waste '97, Fort Collins, Colorado, USA, Rotterdam, The Netherlands, pp. 401-404.

Murrell, M.T., Goldstein, S.J., Dixon, P.R. (2002). Uranium Decay Series Mobility at Peña Blanca, Mexico: Implications for Nuclear Repository Stability. Proceedings of the $8^{\text {th }}$ EC Natural Analogue Working Group Meeting, Nuclear Science and Technology (EUR 19118 EN), Strasbourg, France.

Natrajan, L.S., Swinburne, A.N., Andrews, M.G., Randall, S., Heath, S.L. (2014). Redox and environmentally relevant aspects of actinide (IV) coordination chemistry. Coord. Chem. Rev., 266-267, 171-193.

Neymark, L.A., Amelin, Y.V. (2008). Natural radionuclide mobility and its influence on U-Th$\mathrm{Pb}$ dating of secondary minerals from the unsaturated zone at Yucca Mountain, Nevada. Geochim. Cosmochim. Acta, 72, 2067-2089.

Neymark, L.A., Paces, J.B. (2000). Consequences of slow growth for ${ }^{230} \mathrm{Th} / \mathrm{U}$ dating of Quaternary opals, Yucca Mountain, NV, USA. Chem. Geol., 164, 143-160.

Paces, J.B., Neymark, L.A., Wooden, J.L., Persing, H.M. (2004). Improved spatial resolution for U-series dating of opal at Yucca Mountain, Nevada, USA, using ion-microprobe and microdigestion methods. Geochim. Cosmochim. Acta, 68(7), 1591-1606.

Paces, J.B., Nichols, P.J., Neymark, L.A., Rajaram, H. (2013). Evaluation of Pleistocene groundwater flow through fractured tuffs using a U-series disequilibrium approach, Pahute Mesa, Nevada, USA. Chem. Geol., 358, 101-118.

Payne, T.E., Airey, P.L. (2006). Radionuclide migration at the Koongarra uranium deposit, Northern Australia - Lessons from the Alligator Rivers analogue project. Phys. Chem. Earth, 31, 572-586.

Pearcy, E., Prikryl, J., Murphy, W., Leslie, B. (1994). Alteration of uraninite from the Nopal I deposit, Peña Blanca district, Chihuahua, Mexico, compared to degradation of spent nuclear fuel in the proposed US high-level nuclear waste repository at Yucca Mountain, Nevada. Appl. Geochem., 9, 713-732.

Pearcy, E., Prikryl, J., Leslie, B. (1995). Uranium transport through fractured silicic tuff and relative retention in areas with distinct fracture characteristics. Appl. Geochem., 10, 685-704.

Pickett, D.A., Murrell, M.T., Williams, R.W. (1994). Determination of femtogram quantities of protactinium in geologic samples by thermal ionization mass spectrometry. Anal. Chem., 66, 1044-1049.

Pickett, D.A., Murphy, W.M. (1999). Unsaturated Zone Waters from the Nopal I Natural Analog, Chihuahua, Mexico - Implications for Radionuclide Mobility at Yucca Mountain, in 
Wronkievicz, D.J., Lee, J (Eds), Scientific Basis for Nuclear Waste Management XXII, Materials Research Society, Warrendale, Pennsylvania, 556, pp. 809-816.

Pomiés, C., Hamelin, B., Lancelot, J., Blomqvist, R. (2004). ${ }^{207} \mathrm{~Pb} /{ }^{206} \mathrm{~Pb}$ and ${ }^{238} \mathrm{U} /{ }^{230} \mathrm{Th}$ dating of uranium migration in carbonate fractures from the Palmottu uranium ore (southern Finland). Appl. Geochem.

Porcelli, D., Swarzenski, P.W. (2003). The behavior of U- and Th-series nuclides in groundwater, in Bourdon, B., Henderson, G.M., Lundstrom, C.C., Turner, S.P. (Eds), Rev. Mineral. Geochem., 52, pp. 317-361.

Prikryl, J.D., Pickett, D.A., Murphy, W.M., Pearcy, E.C. (1997). Migration behavior of naturally occurring radionuclides at the Nopal I uranium deposit, Chihuahua, Mexico. J. Contam. Hydrol. 26, 61-69.

Reyes-Cortés, I. (1997). Geologic Studies in the Sierra de Peña Blanca, Chihuahua, México. Ph.D. Thesis, Department of Geological Sciences, the University of Texas at El Paso.

Reyes-Cortés, I. (2002). Geologic Setting and Mineralisation: Sierra Peña Blanca, Chihuahua, México, in von Maravic, H., Alexander, W (Eds.), Proceedings of the Eighth EC Natural Analogue Working Group Meeting, Office of Official Publications of the European Communities, Luxembourg, Luxembourg, pp. 321-331.

Robert, J., Miranda, C.F., Muxart, R. (1969). Mesure de la periode du Protactinium-231 par microcalorimetrie. Radiochim. Acta, 11, 104-108.

Rodriguez Torres, R., Yza Dominguez, R., Chavez Aguirre, R., Constantino, S. (1976). Rocas Volcanicas Acidas y su Potencial como Objectivos para Prospectar Uranio, in Exploration for uranium ore deposits: proceedings from a symposium on Exploration of Uranium Ore Deposits, IAEA, Vienna, Austria, pp. 601-623.

Sachs, S., Bernhard, G. (2011). Influence of humic acids on the actinide migration in the environment: suitable humic acid model substances and their application in studies with uranium - a review. J. Radioanal. Nucl. Chem., 290, 17-29.

Salbu, B., Krekling, T., Oughton, D.H., Østby, G., Kashparov, V.A., Brand, T.L., Day, J.P. (1994). Hot Particles in Accidental Releases from Chernobyl and Windscale Nuclear Installations. Analyst, 119, 125-130.

Schindler, M., Fayek, M., Hawthorne, F.C. (2010). Uranium-rich opal from the Nopal I uranium deposit, Peña Blanca, Mexico: Evidence for the uptake and retardation of radionuclides. Geochim. Cosmochim. Acta, 74, 187-202.

Stirling, C.H., Lee, D.-C., Christensen, J.N., Halliday, A.N. (2000). High-precision in situ ${ }^{238}$ U${ }^{234} \mathrm{U}^{2}{ }^{20} \mathrm{Th}$ isotopic analysis using laser ablation multiple-collector ICPMS. Geochim. Cosmochim. Acta, 64 (21), 3737-3750. 
Stirling, C. H., Andersen, M.B., Potter, E.-K., Halliday, A.N. (2007). Low-temperature isotopic fractionation of uranium. Earth Planet. Sci. Lett., 264, 208-225.

Thiel, K., Vorwerk, R., Saager, R., Stupp, H.D. (1983). ${ }^{235}$ U fission tracks and ${ }^{238}$ U-series disequilibria as a means to study recent mobilization of uranium in Archaean pyritic conglomerates. Earth Planet. Sci. Letters, 65, 249-262.

Tinnacher, R.M., Zavarin, M., Powell, B.A., Kersting, A.B. (2011). Kinetics of neptunium(V) sorption and desorption on goethite: An experimental and modeling study. Geochim. Cosmochim. Acta, 75, 6584-6599.

Um, W., Icenhower, J.P., Brown, C.F., Serne, R.J., Wang, Z., Dodge, C.J., Francis, A.J. (2010). Characterization of uranium-contaminated sediments from beneath a nuclear waste storage tank from Hanford, Washington: Implications for contaminant transport and fate. Geochim, Cosmochim. Acta, 74, 1363-1380.

Vazquez, J.A., Lidzbarski, M.I. (2012). High-resolution tephrochronology of the Wilson Creek Formation (Mono Lake, California) and Laschamp event using U-238-Th-230 SIMS dating of accessory mineral rims. Earth Planet. Sci. Lett., 357, 54-67.

Vodyanitskii, Y.N. (2011). Chemical Aspects of Uranium Behavior in Soils: A Review. Eurasian Soil Sci., 44(8), 862-873.

Volpe, A.M., Olivares, J.A., Murrell, M.T. (1991). Determination of radium isotopes ratios and abundances in geologic samples by thermal ionization mass spectrometry. Anal. Chem., 63, 913916.

Wersin, P., Hochella Jr., M.F., Persson, P., Redden, G., Leckie, J.O., Harris, D.W. (1994). Interaction between aqueous uranium (VI) and sulfide minerals: Spectroscopic evidence for sorption and reduction. Geochim. Cosmochim. Acta, 58(13), 2829-2843.

Yusan, S.D., Erenturk, S.A. (2011). Sorption behaviors of uranium (VI) ions on $\alpha-\mathrm{FeOOH}$. Desalination, 269, 58-66. 


\section{Figure captions:}

Figure 1 Location map of the Nopal I uranium deposit at Peña Blanca after Pearcy et al. (1994).

Figure 2 Schematic location map of surface fractures at the Nopal I uranium deposit at Peña Blanca after Pearcy et al. (1995). The dark gray area represents the area of U mineralization visible to the naked eye. The light gray area represents cleared land. The red circle shows the location of the PB1 drill core relative to the ore deposit based on coordinates given in Dobson et al. (2008).

Figure 3 Stratigraphic column for core PB-1 at the Nopal I uranium deposit at Peña Blanca (after Dobson et al., 2008) with location and photographs of samples analyzed as part of this study (a) sample PB1023774, (b) sample PB1023849 and (c) sample PB1024009. Scale bar $=1 \mathrm{~cm}$.

Figure 4 Graphs of $U$ concentration with horizontal distance from the origin of the fracture in (a) all samples, (b) fracture B, (c) fracture E, and (d) fracture F. Analytical uncertainties are smaller than the symbol size. There is an overall decrease in $U$ concentration versus distance from the deposit, as was observed in previous studies (Pearcy et al., 1995; Prikryl et al., 1997).

Figure 5 Concentrations of uranium (black symbols) and thorium (gray symbols) in the drill core sub-samples with depth below the surface. Uranium concentrations are quite high and exceed the typical value for the deposit in two cases. Analytical uncertainties are smaller than the symbol size. See Figure 3 for geological key.

Figure 6 Graph showing the ${ }^{234} U /{ }^{238} U$ activity ratios as a function of uranium concentration. Analytical uncertainties are smaller than the symbol size. All activity ratios are greater or less than unity illustrating a complex multi-stage evolution consistent with interaction between groundwater enriched in ${ }^{234} \mathrm{U}$ and a tuff matrix depleted in ${ }^{234} \mathrm{U}$ due to recoil-related leaching.

Figure 7 Graph showing ${ }^{226} \mathrm{Ra} /{ }^{230} \mathrm{Th}$ activity ratio as a function of distance from the origin of the fracture. Analytical uncertainties are smaller than the symbol size. Deviations from secular equilibrium indicate some open system behavior for Ra, namely recent $(<8 \mathrm{ka}){ }^{226} \mathrm{Ra}$ loss relative to ${ }^{230} \mathrm{Th}$. This evidence for Ra mobility agrees with prior vegetation (Leslie et al., 1999) and unsaturated zone (UZ) groundwater studies (Goldstein et al., 2010) indicating high Ra mobility in the UZ near the deposit.

Figure 8 Graph showing ${ }^{231} \mathrm{~Pa} /{ }^{235} \mathrm{U}$ activity ratio as a function of distance from the origin of the fracture. Analytical uncertainties are smaller than the symbol size. The large majority of samples are within analytical uncertainty of secular equilibrium indicating closed system ${ }^{235} \mathrm{U}-{ }^{231} \mathrm{~Pa}$ behavior and yield ${ }^{231} \mathrm{~Pa}^{2}{ }^{235} \mathrm{U}$ model ages $>185 \mathrm{ka}$.

Figure 9 Graph showing the ${ }^{234} \mathrm{U} /{ }^{238} \mathrm{U}$ activity ratio plotted against the ${ }^{230} \mathrm{Th} /{ }^{234} \mathrm{U}$ activity ratio. Analytical uncertainties are smaller than the symbol size. Blue lines represent change in activity ratios with time for different initial ${ }^{234} \mathrm{U} /{ }^{238} \mathrm{U}$ activity ratios. Gray solid lines are isochrons with some ages identified. Most of the samples have ${ }^{230} \mathrm{Th} /{ }^{234} \mathrm{U}$ activity ratios slightly greater but 25 
outside of uncertainties of secular equilibrium, and yield ${ }^{230} \mathrm{Th}^{-232} \mathrm{Th}^{-234} \mathrm{U}-{ }^{238} \mathrm{U}$ model ages $>313$ $\mathrm{ka}$ for the surface fractures and $>183 \mathrm{ka}$ for the drill core. There are a few exceptions to this, situated in the forbidden zone, which suggest open system behavior for $\mathrm{U}$.

Figure 10 Linear trends plotting (a) ${ }^{234} \mathrm{U} /{ }^{232} \mathrm{Th}$ activity ratio $v s .{ }^{238} \mathrm{U} /{ }^{232} \mathrm{Th}$ activity ratio and (b) ${ }^{230} \mathrm{Th} /{ }^{232} \mathrm{Th}$ activity ratio $v s .{ }^{234} \mathrm{U} /{ }^{232} \mathrm{Th}$ activity ratio. The slopes of the linear trends correspond to ${ }^{234} \mathrm{U} /{ }^{238} \mathrm{U}$ and ${ }^{230} \mathrm{Th} /{ }^{234} \mathrm{U}$ activity ratios, which are used to calculate an age of closure with respect to U-Th mobility for the fracture samples. Analytical uncertainties are smaller than the symbol size. The linear trend ages are $440 \pm 30 \mathrm{ka}(2 \sigma)$ for the near surface sample PB1023774 and $210 \pm 20 \mathrm{ka}$ for the deepest sample PB1024009. Sample PB1023849 at $67 \mathrm{~m}$ does not plot a linear age trend for $\left({ }^{234} \mathrm{U}\right) /\left({ }^{232} \mathrm{Th}\right) v s .\left({ }^{238} \mathrm{U}\right) /\left({ }^{232} \mathrm{Th}\right)$ indicating open system behavior for $\mathrm{U} . \mathrm{R}^{2}$ values for the linear trends in (a) are as follows: PB1023774 $=0.9994$, PB $1024009=0.9983$. $\mathrm{R}^{2}$ values for the linear trends in (b) are as follows: PB1023774 $=0.9998$, PB1023849 $=0.9984$, PB1024009 $=0.9950$.

Figure 11 Timeline of radionuclide mobility using data from this study together with previous data on the age of precipitated secondary minerals up to 3.1 Ma (Fayek et al., 2006). Ox. represents oxidizing conditions and Red. represents reducing conditions. $U$ has been mobile from (1.2-0.2 Ma) due to redox condition changes and mineral-fluid interaction. $\mathrm{U}$ appears to have been mostly immobile with mobility evident at some locations, sample dependent, in the last 0.2 Ma. Th-Pa radionuclides have been immobile for the last $200 \mathrm{ka}$ and radium has been mobile for the last 0.1-8 ka due to ongoing mineral-fluid interaction. 


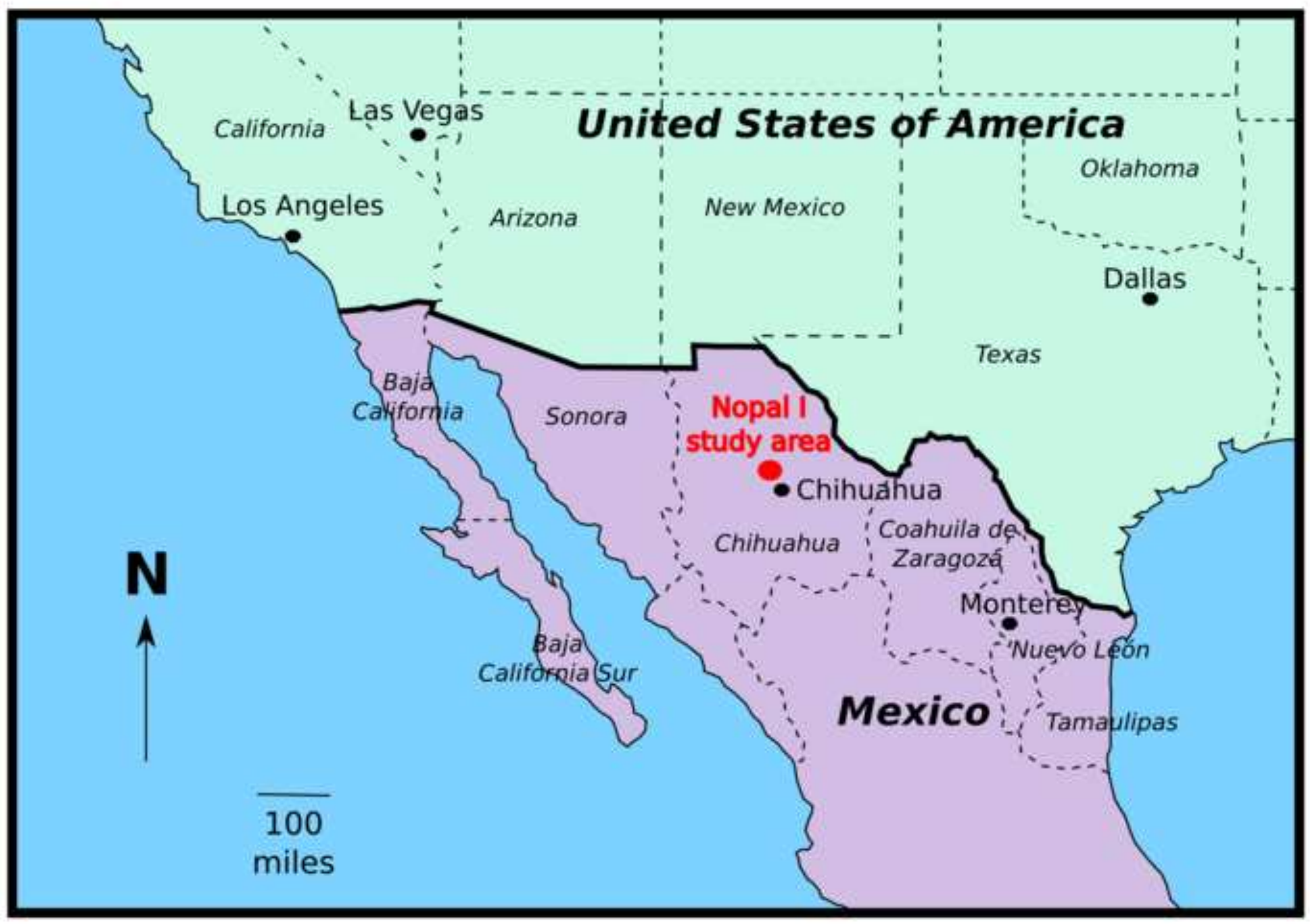




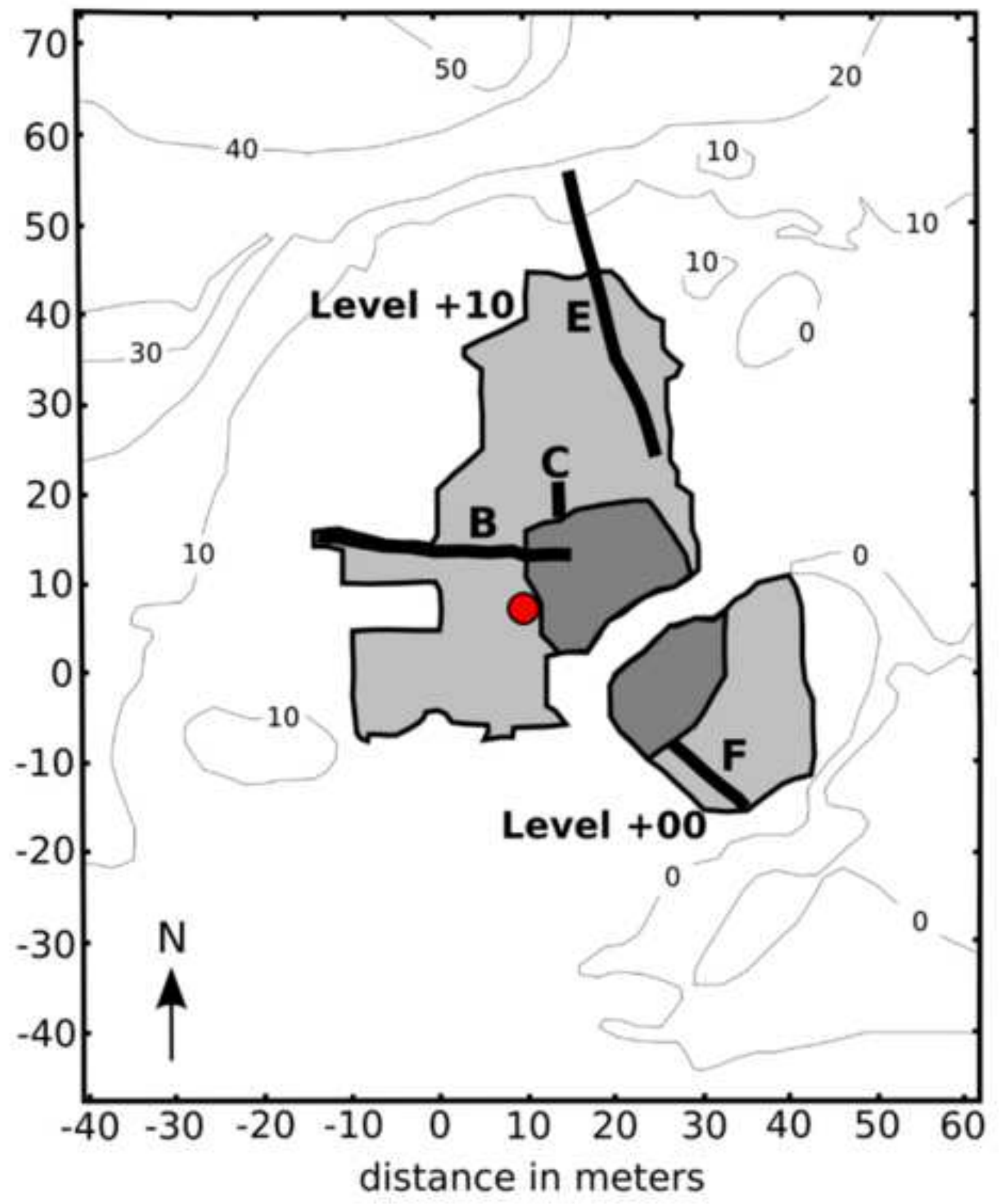




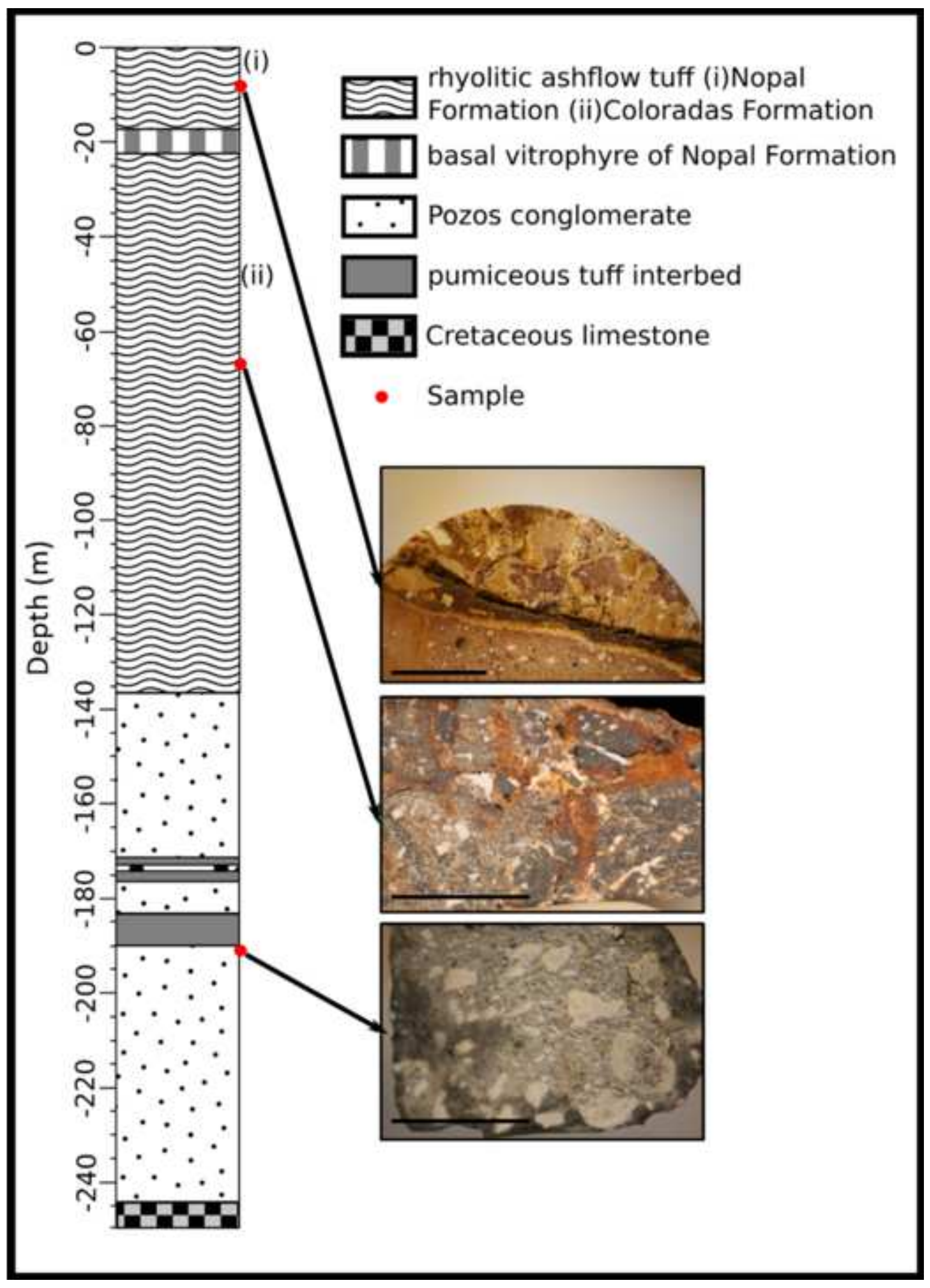









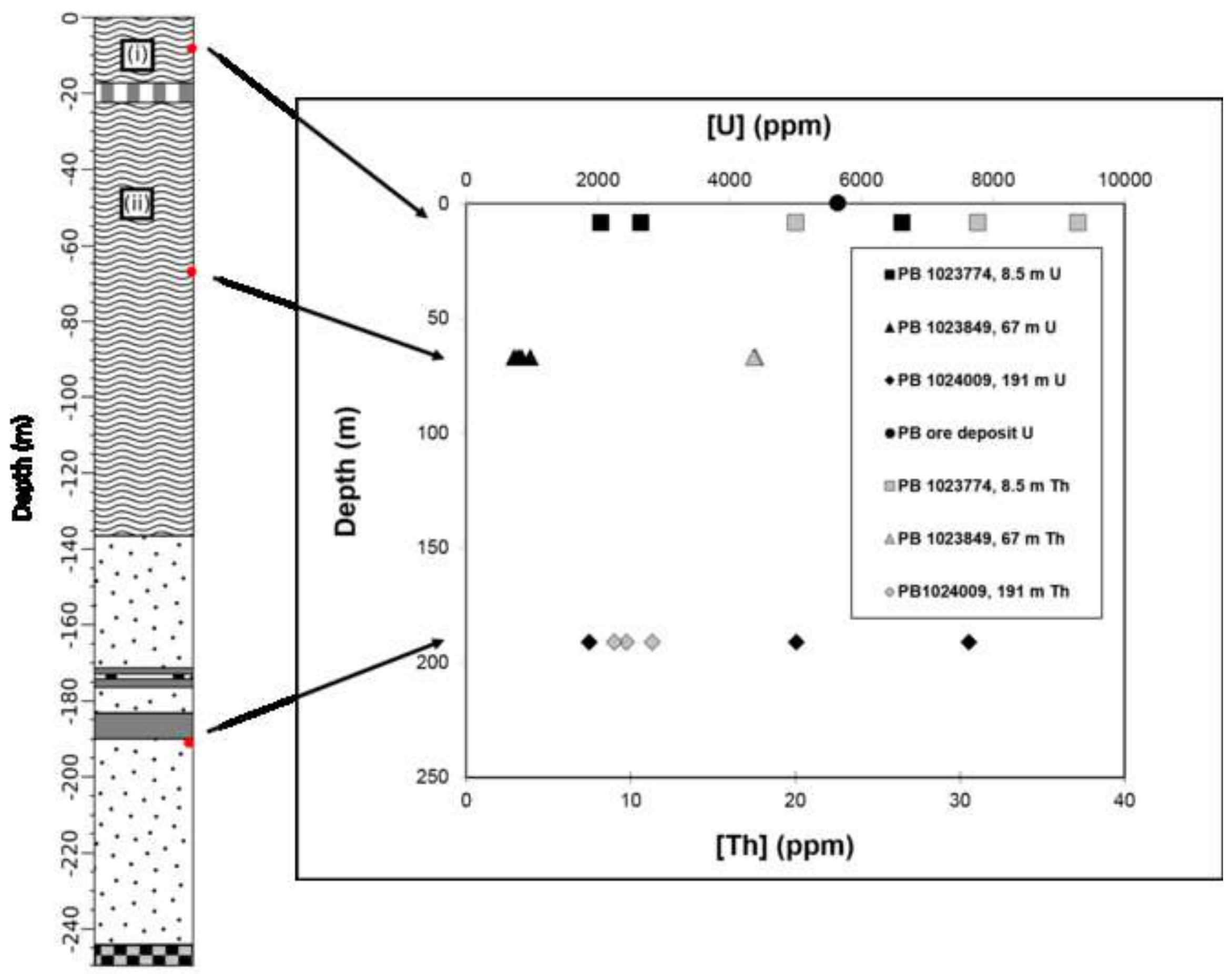




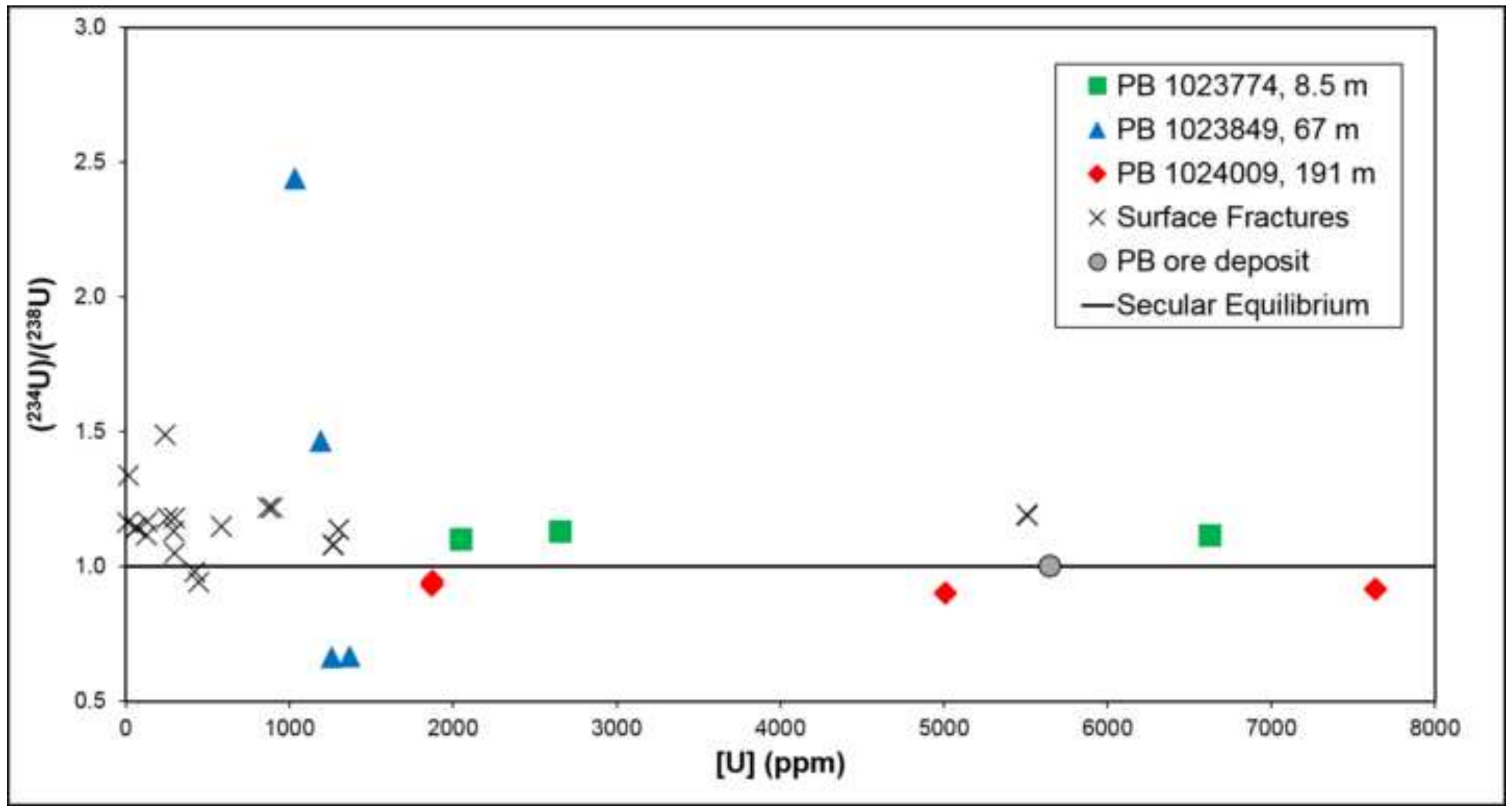




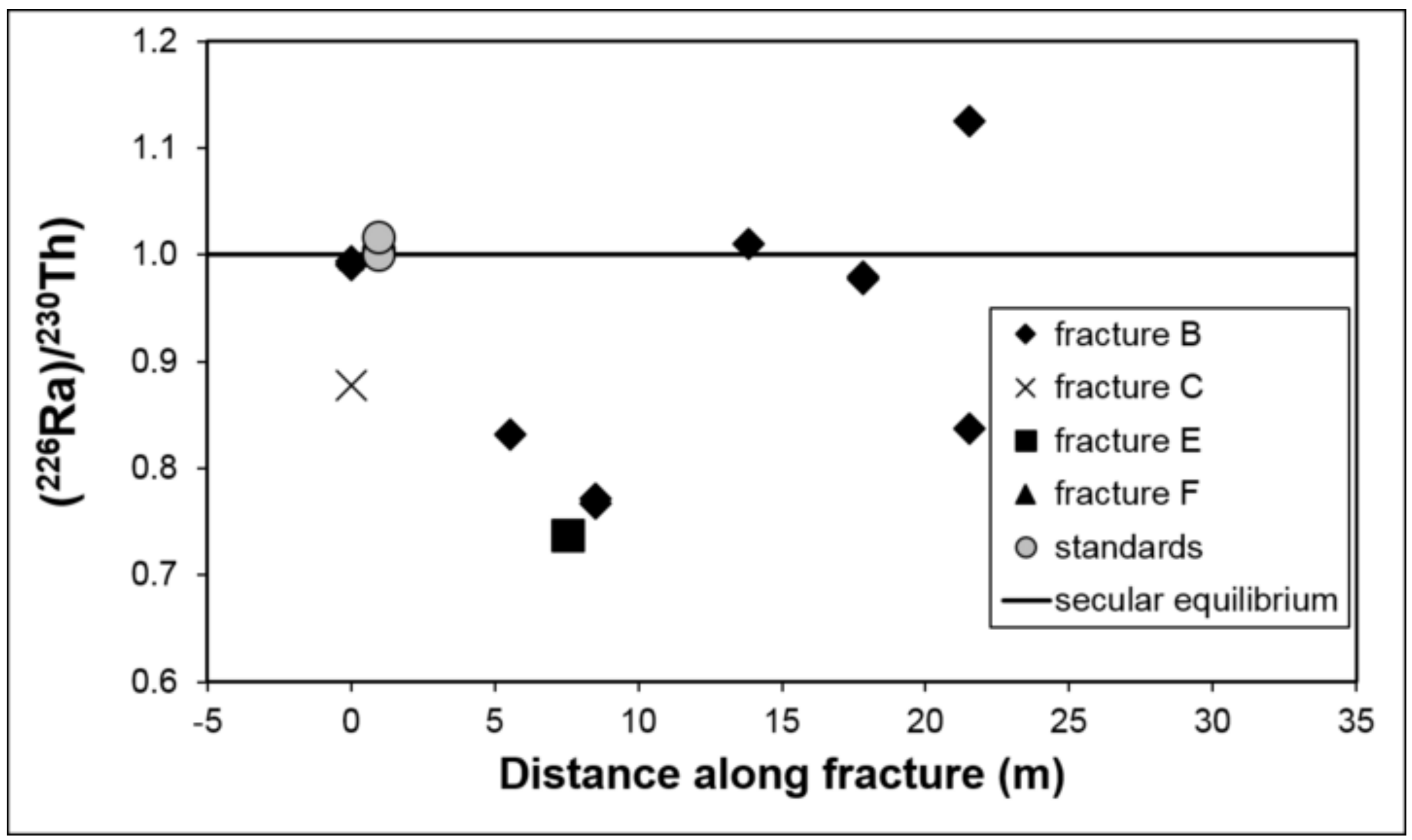




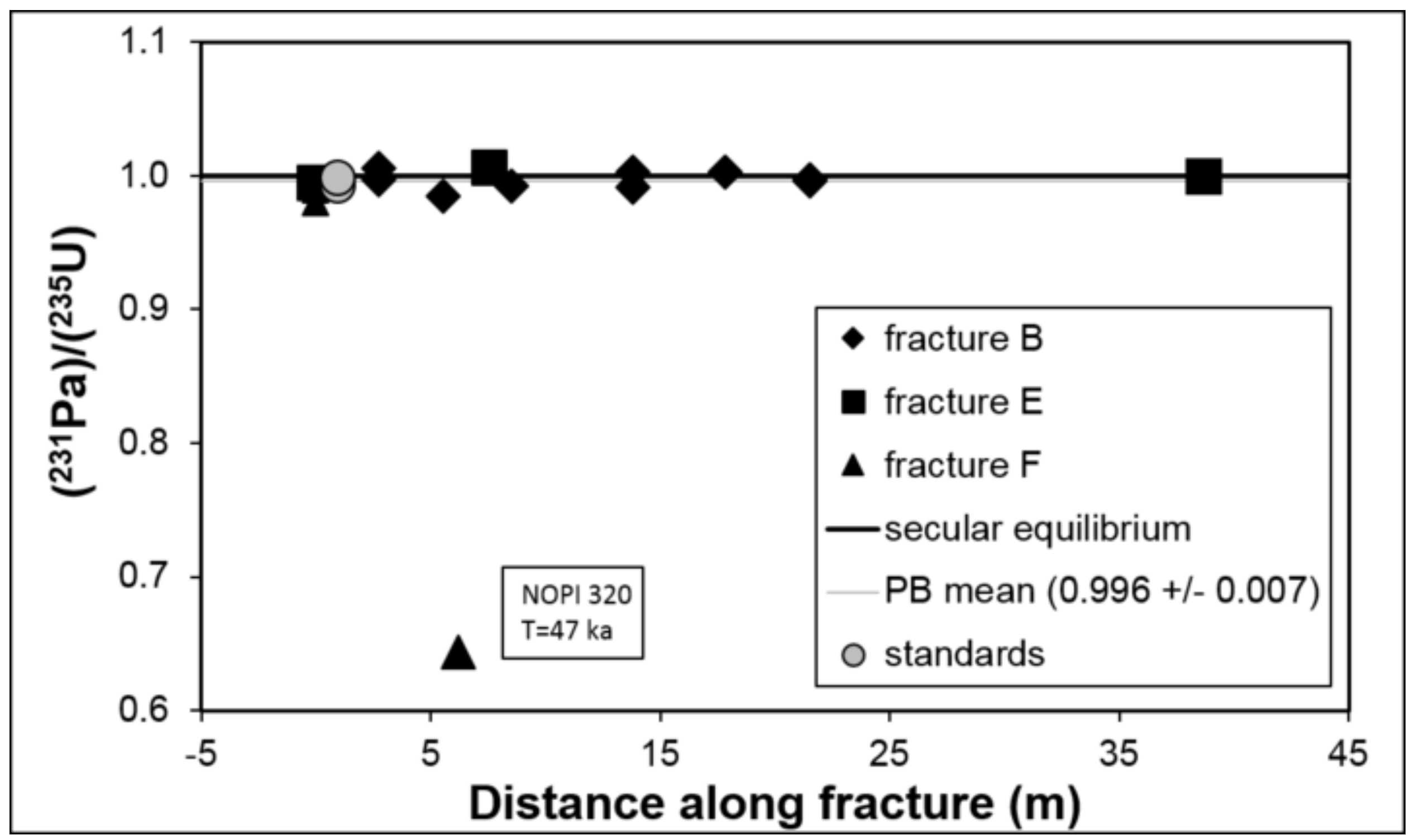




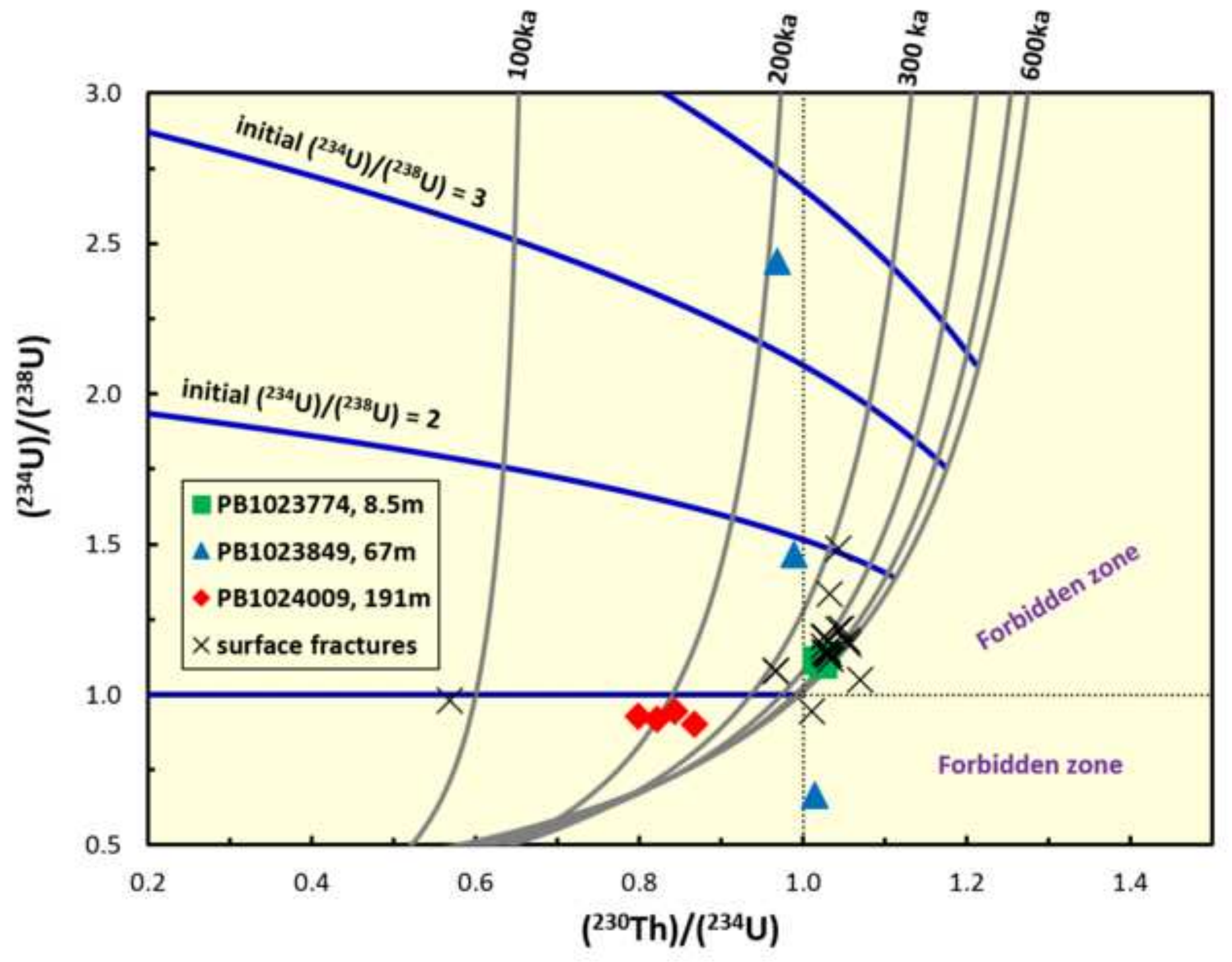



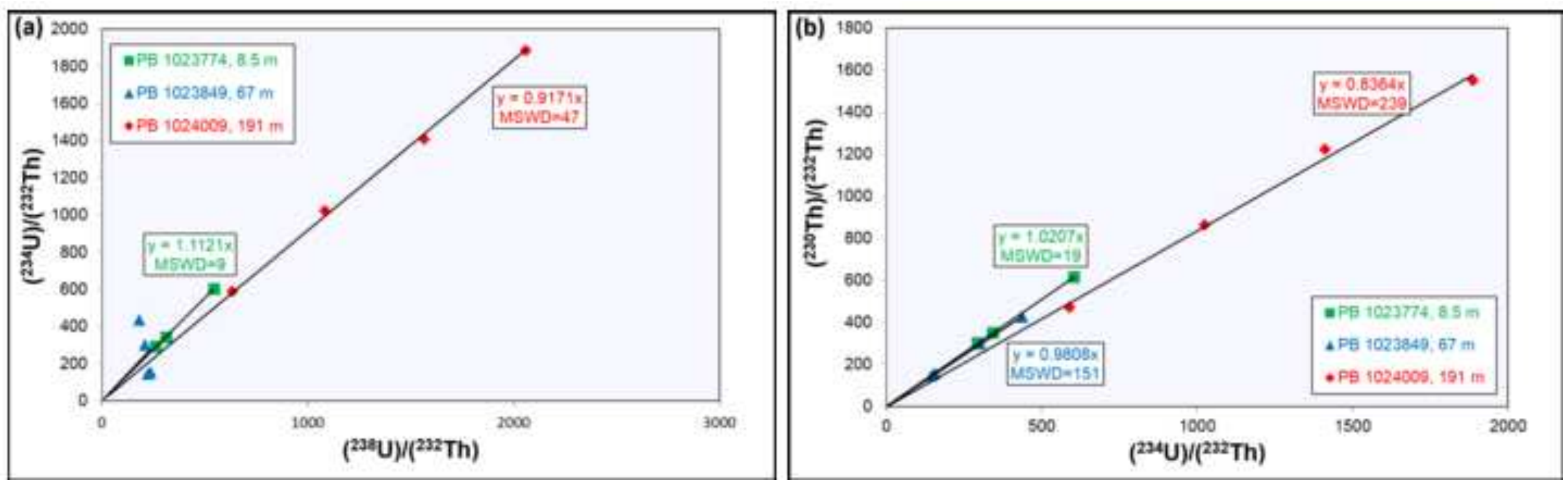


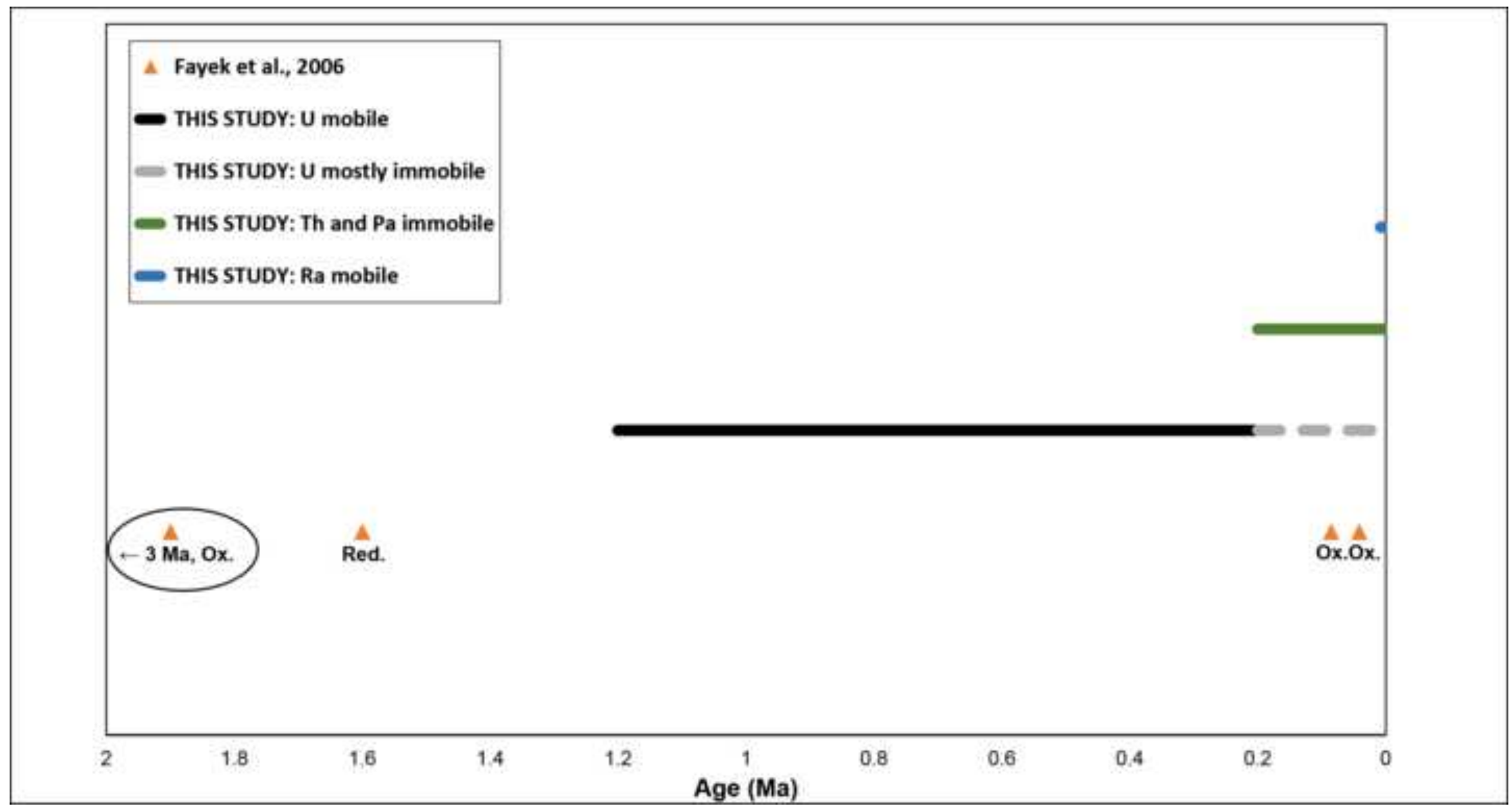


Table 1 Decay constants used for the calculation of activities

\begin{tabular}{|c|c|c|}
\hline Isotope & Decay constant $\left(a^{-1}\right)$ & Reference \\
\hline${ }^{238} \mathrm{U}$ & $1.551 \times 10^{-10}$ & Jaffey et al., 1971 \\
\hline${ }^{235} \mathrm{U}$ & $9.8485 \times 10^{-10}$ & Jaffey et al., 1971 \\
\hline${ }^{234} \mathrm{U}$ & $2.8263 \times 10^{-6}$ & Cheng et al., 2000 \\
\hline${ }^{232} \mathrm{Th}$ & $4.951 \times 10^{-11}$ & Audi et al., 2012 \\
\hline${ }^{230} \mathrm{Th}$ & $9.1577 \times 10^{-6}$ & Cheng et al., 2000 \\
\hline${ }^{231} \mathrm{~Pa}$ & $2.116 \times 10^{-5}$ & Robert et al., 1969 \\
\hline${ }^{226} \mathrm{Ra}$ & $4.332 \times 10^{-4}$ & $\begin{array}{c}\text { Akovali, } 1996 \text { and references } \\
\text { therein }\end{array}$ \\
\hline
\end{tabular}


Table 2 Uranium, thorium, thorium/uranium ratio, radium and protactinium concentrations of the drill core and surface fracture samples and rock standards.

\begin{tabular}{|c|c|c|c|c|c|c|}
\hline \multicolumn{7}{|c|}{ Drill core samples } \\
\hline Sample & $\begin{array}{c}\text { Distance from } \\
\text { surface }(\mathbf{m})\end{array}$ & {$[\mathbf{U}]\left(\boldsymbol{\mu} \mathbf{g ~ g}^{-1}\right)$} & {$[\mathrm{Th}]\left(\mu \mathrm{g} \mathrm{g}^{-1}\right)$} & Th/U (wt.) & [Ra] $\left(\right.$ fmoles $\left.g^{-1}\right)$ & {$[\mathrm{Pa}]\left(\right.$ fmoles $\left.\mathrm{g}^{-1}\right)$} \\
\hline PB1023774-1 & 8.5 & $2657.4 \pm 6.2$ & $31.12 \pm 0.11$ & $0.011711 \pm 0.000048$ & - & - \\
\hline PB1023774-2 & 8.5 & $6628 \pm 16$ & $37.21 \pm 0.13$ & $0.005614 \pm 0.000023$ & - & - \\
\hline PB1023774-3 & 8.5 & $2052.3 \pm 4.7$ & $20.066 \pm 0.068$ & $0.009778 \pm 0.000040$ & - & - \\
\hline PB1023849-1 & 67.0 & $1031.9 \pm 2.5$ & $17.485 \pm 0.058$ & $0.016946 \pm 0.000069$ & - & - \\
\hline PB1023849-2 & 67.0 & $1193.7 \pm 3.6$ & $17.594 \pm 0.060$ & $0.014740 \pm 0.000066$ & - & - \\
\hline $\begin{array}{c}\text { PB1023849-3- } \\
\text { pd1 }\end{array}$ & 67.0 & $1260.5 \pm 3.1$ & $17.468 \pm 0.059$ & $0.013858 \pm 0.000057$ & - & - \\
\hline $\begin{array}{c}\text { PB1023849-3- } \\
\text { pd2 }\end{array}$ & 67.0 & $1369.6 \pm 3.4$ & $17.772 \pm 0.059$ & $0.012976 \pm 0.000054$ & - & - \\
\hline PB1024009-1 & 191.0 & $5009 \pm 13$ & $9.746 \pm 0.033$ & $0.0019459 \pm 0.0000083$ & - & - \\
\hline PB1024009-2 & 191.0 & $7635 \pm 21$ & $11.285 \pm 0.038$ & $0.0014781 \pm 0.0000065$ & - & - \\
\hline PB1024009-3 & 191.0 & $1870.1 \pm 4.5$ & $8.977 \pm 0.030$ & $0.004800 \pm 0.000020$ & - & - \\
\hline PB1024009-4 & 191.0 & $1872.5 \pm 4.9$ & $5.267 \pm 0.018$ & $0.002813 \pm 0.000012$ & - & - \\
\hline \multicolumn{7}{|c|}{ Surface fracture samples } \\
\hline Sample & $\begin{array}{l}\text { Distance from origin } \\
\text { of fracture (m) }\end{array}$ & {$[\mathbf{U}]\left(\boldsymbol{\mu} \mathbf{g ~ g}^{-1}\right)$} & {$[\mathrm{Th}]\left(\mu \mathrm{g} \mathrm{g}^{-1}\right)$} & Th/U (wt.) & [Ra] $\left(\right.$ fmoles $\left.g^{-1}\right)$ & {$[\mathrm{Pa}]\left(\right.$ fmoles g $\left.^{-1}\right)$} \\
\hline \multicolumn{7}{|l|}{ Fracture B } \\
\hline NOPI-418-pd1 & 0.0 & $5507 \pm 33$ & $15.955 \pm 0.057$ & $0.002897 \pm 0.000020$ & $9965 \pm 64$ & $7670 \pm 44$ \\
\hline NOPI-418-pd2 & 0.0 & $5510 \pm 21$ & $15.955 \pm 0.055$ & $0.002896 \pm 0.000015$ & $9980 \pm 61$ & $7686 \pm 55$ \\
\hline NOPI-419-sd1 & 2.7 & $238.62 \pm 0.25$ & $28.90 \pm 0.10$ & $0.12110 \pm 0.00045$ & - & $334.9 \pm 2.5$ \\
\hline NOPI-419-sd2 & 2.7 & - & - & - & - & $337.8 \pm 2.6$ \\
\hline NOPI-420-pd1 & 5.5 & $1303.5 \pm 1.8$ & $26.861 \pm 0.087$ & $0.020607 \pm 0.000072$ & $1895 \pm 18$ & $1807 \pm 14$ \\
\hline NOPI-420-pd2 & 5.5 & $1302.9 \pm 1.8$ & $26.929 \pm 0.085$ & $0.020668 \pm 0.000071$ & - & - \\
\hline NOPI-421-1 & 8.5 & $871.0 \pm 4.1$ & $36.01 \pm 0.12$ & $0.04134 \pm 0.00024$ & $1266.7 \pm 5.9$ & $1217.3 \pm 7.8$ \\
\hline NOPI-421-2 & 8.5 & $893.2 \pm 1.5$ & $36.47 \pm 0.11$ & $0.04083 \pm 0.00014$ & $1314.9 \pm 8.5$ & - \\
\hline NOPI-423-1 & 13.8 & $583.13 \pm 0.71$ & $49.48 \pm 0.17$ & $0.08485 \pm 0.00031$ & - & $823.6 \pm 7.1$ \\
\hline NOPI-423-2 & 13.8 & $299.82 \pm 0.28$ & $37.03 \pm 0.13$ & $0.12350 \pm 0.00044$ & $563.0 \pm 3.1$ & $418.4 \pm 2.6$ \\
\hline NOPI-424-sd1 & 17.8 & $61.74 \pm 0.11$ & - & - & $106.23 \pm 0.66$ & $87.20 \pm 0.76$ \\
\hline NOPI-424-sd2 & 17.8 & - & - & - & $106.01 \pm 0.51$ & - \\
\hline NOPI-424-sd3 & 17.8 & $61.962 \pm 0.053$ & $35.00 \pm 0.11$ & $0.5648 \pm 0.0019$ & - & - \\
\hline
\end{tabular}




\begin{tabular}{|c|c|c|c|c|c|c|}
\hline NOPI-425-1 & 21.5 & $295.6 \pm 1.4$ & $34.73 \pm 0.11$ & $0.11749 \pm 0.00069$ & $431.3 \pm 3.0$ & $415.1 \pm 3.1$ \\
\hline NOPI-425-2 & 21.5 & $127.95 \pm 0.15$ & $38.05 \pm 0.13$ & $0.2974 \pm 0.0011$ & $248.4 \pm 1.3$ & $179.5 \pm 1.5$ \\
\hline \multicolumn{7}{|l|}{ Fracture C } \\
\hline NOPI-376 & 0.0 & $256.26 \pm 0.27$ & $32.04 \pm 0.10$ & $0.12504 \pm 0.00041$ & $418.2 \pm 3.6$ & - \\
\hline \multicolumn{7}{|l|}{ Fracture E } \\
\hline NOPI-403 & 0.0 & $299.67 \pm 0.34$ & $38.50 \pm 0.13$ & $0.12846 \pm 0.00046$ & - & $419.3 \pm 3.3$ \\
\hline NOPI-404 & 1.7 & $131.98 \pm 0.11$ & $36.38 \pm 0.12$ & $0.27564 \pm 0.00093$ & - & - \\
\hline NOPI-407 & 7.6 & $444.20 \pm 0.62$ & $36.69 \pm 0.12$ & $0.08259 \pm 0.00030$ & $465.6 \pm 4.9$ & $629.1 \pm 5.0$ \\
\hline NOPI-410 & 38.7 & $12.659 \pm 0.022$ & $42.34 \pm 0.13$ & $3.345 \pm 0.012$ & - & $17.81 \pm 0.13$ \\
\hline NOPI-411 & 38.7 & $14.809 \pm 0.021$ & $36.45 \pm 0.13$ & $2.4611 \pm 0.0094$ & - & $20.83 \pm 0.18$ \\
\hline \multicolumn{7}{|l|}{ Fracture F } \\
\hline NOPI-309-sd1 & 0.0 & $1266.2 \pm 1.2$ & $34.75 \pm 0.11$ & $0.027440 \pm 0.000089$ & $1967 \pm 24$ & $1748 \pm 12$ \\
\hline NOPI-309-sd2 & 0.0 & $1267.1 \pm 1.2$ & $34.79 \pm 0.13$ & $0.02745 \pm 0.00010$ & - & $1765 \pm 12$ \\
\hline NOPI-320 & 6.3 & $424.34 \pm 0.52$ & $27.595 \pm 0.098$ & $0.06503 \pm 0.00024$ & - & $384.5 \pm 3.0$ \\
\hline \multicolumn{7}{|c|}{ Standards } \\
\hline TML-97B-sd1 & & $10.899 \pm 0.010$ & $30.46 \pm 0.11$ & $2.795 \pm 0.010$ & $16.329 \pm 0.072$ & - \\
\hline TML-97B-sd2 & & $10.885 \pm 0.010$ & $30.623 \pm 0.094$ & $2.8134 \pm 0.0090$ & $16.182 \pm 0.090$ & $15.205 \pm 0.093$ \\
\hline BL4 & & $1714.8 \pm 1.5$ & $12.222 \pm 0.042$ & $0.007127 \pm 0.000025$ & $2591 \pm 14$ & $2409 \pm 16$ \\
\hline
\end{tabular}

Uncertainties are 2xSEM (absolute). 
Table 3 Uranium, thorium, radium and protactinium atomic and activity ratios in the drill core and surface fracture samples and the rock standards.

\begin{tabular}{|c|c|c|c|c|c|c|c|c|c|c|}
\hline \multicolumn{11}{|c|}{ Drill core samples } \\
\hline Sample & $\begin{array}{l}\text { Distance } \\
\text { from } \\
\text { surface } \\
(\mathbf{m})\end{array}$ & $\begin{array}{l}\left({ }^{238} \mathrm{U}\right) / \\
\left({ }^{232} \mathrm{Th}\right)\end{array}$ & $\begin{array}{c}{ }^{230} \mathrm{Th} /{ }^{232} \mathrm{Th} \\
(\mathrm{ppm})\end{array}$ & $\begin{array}{l}\left({ }^{230} \mathrm{Th}\right) / \\
\left({ }^{232} \mathrm{Th}\right)\end{array}$ & $\begin{array}{l}{ }_{(\mathbf{p p m})}^{{ }^{234} \mathbf{U} /{ }^{238} \mathbf{U}} \\
\end{array}$ & $\begin{array}{c}\left({ }^{234} \mathrm{U}\right) / \\
\left({ }^{238} \mathrm{U}\right)\end{array}$ & $\begin{array}{c}\left({ }^{230} \mathrm{Th}\right) / \\
\left({ }^{234} \mathrm{U}\right)\end{array}$ & $\begin{array}{c}\left({ }^{230} \mathrm{Th}\right) / \\
\left({ }^{238} \mathrm{U}\right)\end{array}$ & $\begin{array}{l}\left({ }^{226} \mathbf{R a}\right) / \\
\left({ }^{230} \mathrm{Th}\right)\end{array}$ & $\begin{array}{c}\left({ }^{231} \mathbf{P a}\right) / \\
\left({ }^{235} \mathbf{U}\right)\end{array}$ \\
\hline PB1023774-1 & 8.5 & $\begin{array}{c}259.9 \pm \\
1.1\end{array}$ & $1623.2 \pm 2.0$ & $\begin{array}{c}301.30 \pm \\
0.38\end{array}$ & $61.875 \pm 0.080$ & $\begin{array}{c}1.1273 \pm \\
0.0015\end{array}$ & $\begin{array}{c}1.0285 \pm \\
0.0046\end{array}$ & $\begin{array}{c}1.1594 \pm \\
0.0050 \\
\end{array}$ & - & - \\
\hline PB1023774-2 & 8.5 & $\begin{array}{c}542.1 \pm \\
2.2\end{array}$ & $3307.3 \pm 2.5$ & $\begin{array}{c}613.93 \pm \\
0.47\end{array}$ & $61.103 \pm 0.073$ & $\begin{array}{c}1.1132 \pm \\
0.0013\end{array}$ & $\begin{array}{c}1.0174 \pm \\
0.0044\end{array}$ & $\begin{array}{c}1.1325 \pm \\
0.0048\end{array}$ & - & - \\
\hline PB1023774-3 & 8.5 & $\begin{array}{c}311.3 \pm \\
1.3\end{array}$ & $1888.8 \pm 1.2$ & $\begin{array}{c}350.60 \pm \\
0.22\end{array}$ & $60.286 \pm 0.066$ & $\begin{array}{c}1.0983 \pm \\
0.0012\end{array}$ & $\begin{array}{c}1.0256 \pm \\
0.0044\end{array}$ & $\begin{array}{c}1.1264 \pm \\
0.0047\end{array}$ & - & - \\
\hline PB1023849-1 & 67.0 & $\begin{array}{c}179.60 \pm \\
0.73\end{array}$ & $2286.9 \pm 2.1$ & $\begin{array}{c}424.51 \pm \\
0.39\end{array}$ & $133.88 \pm 0.16$ & $\begin{array}{c}2.4390 \pm \\
0.0029\end{array}$ & $\begin{array}{c}0.9691 \pm \\
0.0042\end{array}$ & $\begin{array}{c}2.3637 \pm \\
0.0099\end{array}$ & - & - \\
\hline PB1023849-2 & 67.0 & $\begin{array}{c}206.48 \pm \\
0.93\end{array}$ & $1610.8 \pm 1.1$ & $\begin{array}{c}299.00 \pm \\
0.20\end{array}$ & $80.42 \pm 0.19$ & $\begin{array}{l}1.4651 \pm \\
0.0035\end{array}$ & $\begin{array}{c}0.9884 \pm \\
0.0050\end{array}$ & $\begin{array}{c}1.4481 \pm \\
0.0066\end{array}$ & - & - \\
\hline $\begin{array}{c}\text { PB1023849-3- } \\
\text { pd1 }\end{array}$ & 67.0 & $\begin{array}{c}219.61 \pm \\
0.91\end{array}$ & $\begin{array}{c}796.67 \pm \\
0.54\end{array}$ & $\begin{array}{c}147.88 \pm \\
0.10\end{array}$ & $36.451 \pm 0.062$ & $\begin{array}{c}0.6641 \pm \\
0.0011\end{array}$ & $\begin{array}{c}1.0140 \pm \\
0.0046\end{array}$ & $\begin{array}{c}0.6734 \pm \\
0.0028 \\
\end{array}$ & - & - \\
\hline $\begin{array}{c}\text { PB1023849-3- } \\
\text { pd2 }\end{array}$ & 67.0 & $\begin{array}{c}234.54 \pm \\
0.98\end{array}$ & $\begin{array}{c}852.51 \pm \\
0.49\end{array}$ & $\begin{array}{c}158.249 \pm \\
0.092\end{array}$ & $36.504 \pm 0.073$ & $\begin{array}{c}0.6650 \pm \\
0.0013\end{array}$ & $\begin{array}{c}1.0146 \pm \\
0.0047\end{array}$ & $\begin{array}{c}0.6747 \pm \\
0.0028\end{array}$ & - & - \\
\hline PB1024009-1 & 191.0 & $\begin{array}{c}1564.0 \pm \\
6.6\end{array}$ & $6586.7 \pm 4.1$ & $\begin{array}{c}1222.66 \pm \\
0.76\end{array}$ & $49.50 \pm 0.11$ & $\begin{array}{c}0.9018 \pm \\
0.0021\end{array}$ & $\begin{array}{c}0.8669 \pm \\
0.0042\end{array}$ & $\begin{array}{c}0.7818 \pm \\
0.0034\end{array}$ & - & - \\
\hline PB1024009-2 & 191.0 & $\begin{array}{c}2058.9 \pm \\
9.0\end{array}$ & $8349.4 \pm 4.5$ & $\begin{array}{c}1549.86 \pm \\
0.84\end{array}$ & $50.32 \pm 0.14$ & $\begin{array}{c}0.9167 \pm \\
0.0026\end{array}$ & $\begin{array}{c}0.8211 \pm \\
0.0043\end{array}$ & $\begin{array}{c}0.7528 \pm \\
0.0033\end{array}$ & - & - \\
\hline PB1024009-3 & 191.0 & $\begin{array}{c}634.0 \pm \\
2.6\end{array}$ & $2535.8 \pm 2.2$ & $\begin{array}{c}470.72 \pm \\
0.41\end{array}$ & $51.022 \pm 0.071$ & $\begin{array}{c}0.9295 \pm \\
0.0013\end{array}$ & $\begin{array}{c}0.7988 \pm \\
0.0036\end{array}$ & $\begin{array}{c}0.7425 \pm \\
0.0031\end{array}$ & - & - \\
\hline PB1024009-4 & 191.0 & $\begin{array}{c}1081.9 \pm \\
4.6\end{array}$ & $4647.2 \pm 3.2$ & $\begin{array}{c}862.63 \pm \\
0.59 \\
\end{array}$ & $51.92 \pm 0.10$ & $\begin{array}{c}0.9459 \pm \\
0.0019\end{array}$ & $\begin{array}{c}0.8429 \pm \\
0.0040 \\
\end{array}$ & $\begin{array}{c}0.7973 \pm \\
0.0034 \\
\end{array}$ & - & - \\
\hline \multicolumn{11}{|c|}{ Surface fracture samples } \\
\hline Sample & $\begin{array}{l}\text { Distance } \\
\text { from } \\
\text { origin of } \\
\text { fracture } \\
\text { (m) }\end{array}$ & $\begin{array}{l}\left({ }^{238} \mathrm{U}\right) / \\
\left({ }^{232} \mathrm{Th}\right)\end{array}$ & $\begin{array}{c}{ }^{230} \mathrm{Th} /{ }^{232} \mathrm{Th} \\
(\mathrm{ppm})\end{array}$ & $\begin{array}{l}\left({ }^{230} \mathrm{Th}\right) / \\
\left({ }^{232} \mathrm{Th}\right)\end{array}$ & 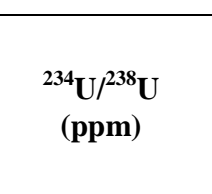 & $\begin{array}{c}\left({ }^{234} \mathrm{U}\right) / \\
\left({ }^{238} \mathrm{U}\right)\end{array}$ & $\begin{array}{c}\left({ }^{230} \mathrm{Th}\right) / \\
\left({ }^{234} \mathrm{U}\right)\end{array}$ & $\begin{array}{c}\left({ }^{230} \mathrm{Th}\right) / \\
\left({ }^{238} \mathrm{U}\right)\end{array}$ & $\begin{array}{l}\left({ }^{226} \mathbf{R a}\right) / \\
\left({ }^{230} \mathrm{Th}\right)\end{array}$ & $\begin{array}{c}\left({ }^{231} \mathbf{P a}\right) / \\
\left({ }^{235} \mathbf{U}\right)\end{array}$ \\
\hline \multicolumn{11}{|l|}{ Fracture B } \\
\hline NOPI-418-pd1 & 0.0 & $\begin{array}{c}1050.5 \pm \\
7.4\end{array}$ & $6925 \pm 12$ & $1285.5 \pm 2.3$ & $65.45 \pm 0.13$ & $\begin{array}{c}1.1923 \pm \\
0.0024\end{array}$ & $\begin{array}{c}1.0263 \pm \\
0.0078\end{array}$ & $\begin{array}{c}1.2237 \pm \\
0.0089\end{array}$ & $\begin{array}{c}0.9900 \pm \\
0.0075\end{array}$ & $\begin{array}{c}0.9891 \pm \\
0.0083\end{array}$ \\
\hline NOPI-418-pd2 & 0.0 & $\begin{array}{c}1050.9 \pm \\
5.5\end{array}$ & $6909 \pm 19$ & $1282.5 \pm 3.6$ & $65.34 \pm 0.13$ & $\begin{array}{c}1.1904 \pm \\
0.0024\end{array}$ & $\begin{array}{c}1.0252 \pm \\
0.0064\end{array}$ & $\begin{array}{c}1.2203 \pm \\
0.0072\end{array}$ & $0.9937 \pm$ & $0.9907 \pm$ \\
\hline
\end{tabular}




\begin{tabular}{|c|c|c|c|c|c|c|c|c|c|c|}
\hline & & & & & & & & & 0.0075 & 0.0081 \\
\hline NOPI-419-sd1 & 2.7 & $\begin{array}{c}25.131 \pm \\
0.093\end{array}$ & $210.2 \pm 1.1$ & $39.02 \pm 0.21$ & $81.64 \pm 0.11$ & $\begin{array}{c}1.4873 \pm \\
0.0021\end{array}$ & $\begin{array}{c}1.0438 \pm \\
0.0069\end{array}$ & $1.552 \pm 0.010$ & - & $\begin{array}{c}0.9968 \pm \\
0.0076\end{array}$ \\
\hline NOPI-419-sd2 & 2.7 & - & - & - & - & - & - & - & - & $\begin{array}{c}1.0055 \pm \\
0.0078 \\
\end{array}$ \\
\hline NOPI-420-pd1 & 5.5 & $\begin{array}{c}147.69 \pm \\
0.52\end{array}$ & $930.9 \pm 1.5$ & $\begin{array}{c}172.79 \pm \\
0.27\end{array}$ & $62.43 \pm 0.12$ & $\begin{array}{c}1.1374 \pm \\
0.0022\end{array}$ & $\begin{array}{c}1.0287 \pm \\
0.0044\end{array}$ & $\begin{array}{c}1.1700 \pm \\
0.0045\end{array}$ & $\begin{array}{c}0.8318 \pm \\
0.0084\end{array}$ & $\begin{array}{c}0.9847 \pm \\
0.0079\end{array}$ \\
\hline NOPI-420-pd2 & 5.5 & $\begin{array}{c}147.25 \pm \\
0.51\end{array}$ & $930.0 \pm 1.7$ & $\begin{array}{c}172.64 \pm \\
0.31\end{array}$ & $62.37 \pm 0.12$ & $\begin{array}{c}1.1362 \pm \\
0.0023\end{array}$ & $\begin{array}{c}1.0319 \pm \\
0.0045\end{array}$ & $\begin{array}{c}1.1724 \pm \\
0.0046\end{array}$ & - & - \\
\hline NOPI-421-1 & 8.5 & $\begin{array}{c}73.61 \pm \\
0.43\end{array}$ & $503.6 \pm 1.4$ & $93.48 \pm 0.26$ & $66.82 \pm 0.13$ & $\begin{array}{c}1.2173 \pm \\
0.0024\end{array}$ & $\begin{array}{c}1.0432 \pm \\
0.0070\end{array}$ & $\begin{array}{c}1.2699 \pm \\
0.0082\end{array}$ & $\begin{array}{c}0.7667 \pm \\
0.0049\end{array}$ & $\begin{array}{c}0.9925 \pm \\
0.0079 \\
\end{array}$ \\
\hline NOPI-421-2 & 8.5 & $\begin{array}{c}74.54 \pm \\
0.26\end{array}$ & $512.6 \pm 1.9$ & $95.15 \pm 0.35$ & $66.90 \pm 0.11$ & $\begin{array}{c}1.2188 \pm \\
0.0021\end{array}$ & $\begin{array}{c}1.0473 \pm \\
0.0056\end{array}$ & $\begin{array}{c}1.2766 \pm \\
0.0065\end{array}$ & $\begin{array}{c}0.7721 \pm \\
0.0062\end{array}$ & - \\
\hline NOPI-423-1 & 13.8 & $\begin{array}{c}35.87 \pm \\
0.13\end{array}$ & $\begin{array}{c}228.38 \pm \\
0.57\end{array}$ & $42.39 \pm 0.10$ & $63.00 \pm 0.12$ & $\begin{array}{c}1.1478 \pm \\
0.0022\end{array}$ & $\begin{array}{c}1.0297 \pm \\
0.0050\end{array}$ & $\begin{array}{c}1.1819 \pm \\
0.0053\end{array}$ & - & $\begin{array}{c}1.0030 \pm \\
0.0088\end{array}$ \\
\hline NOPI-423-2 & 13.8 & $\begin{array}{c}24.64 \pm \\
0.87\end{array}$ & $\begin{array}{c}165.21 \pm \\
0.48\end{array}$ & $\begin{array}{c}30.667 \pm \\
0.088\end{array}$ & $64.82 \pm 0.10$ & $\begin{array}{c}1.1809 \pm \\
0.0019 \\
\end{array}$ & $\begin{array}{c}1.0538 \pm \\
0.0051 \\
\end{array}$ & $\begin{array}{c}1.2444 \pm \\
0.0057\end{array}$ & $\begin{array}{c}1.0103 \pm \\
0.0071 \\
\end{array}$ & $\begin{array}{c}0.9911 \pm \\
0.0062 \\
\end{array}$ \\
\hline NOPI-424-sd1 & 17.8 & - & - & - & $62.82 \pm 0.23$ & $\begin{array}{c}1.1444 \pm \\
0.0041\end{array}$ & - & - & $\begin{array}{c}0.9791 \pm \\
0.0077\end{array}$ & $\begin{array}{c}1.0030 \pm \\
0.0089\end{array}$ \\
\hline NOPI-424-sd2 & 17.8 & - & - & - & - & - & - & - & $\begin{array}{c}0.9771 \pm \\
0.0057\end{array}$ & - \\
\hline NOPI-424-sd3 & 17.8 & $\begin{array}{c}5.388 \pm \\
0.018\end{array}$ & $34.03 \pm 0.17$ & $\begin{array}{c}6.317 \pm \\
0.032\end{array}$ & $62.721 \pm 0.075$ & $\begin{array}{c}1.1427 \pm \\
0.0014\end{array}$ & $\begin{array}{c}1.0259 \pm \\
0.0064\end{array}$ & $\begin{array}{c}1.1723 \pm \\
0.0072\end{array}$ & - & - \\
\hline NOPI-425-1 & 21.5 & $\begin{array}{c}25.90 \pm \\
0.15\end{array}$ & $\begin{array}{c}162.74 \pm \\
0.46\end{array}$ & $\begin{array}{c}30.209 \pm \\
0.085\end{array}$ & $62.13 \pm 0.12$ & $\begin{array}{l}1.1318 \pm \\
0.0023\end{array}$ & $\begin{array}{c}1.0304 \pm \\
0.0070\end{array}$ & $\begin{array}{c}1.1662 \pm \\
0.0076\end{array}$ & $\begin{array}{c}0.8376 \pm \\
0.0069\end{array}$ & $\begin{array}{c}0.9972 \pm \\
0.0089\end{array}$ \\
\hline NOPI-425-2 & 21.5 & $\begin{array}{c}10.234 \pm \\
0.037\end{array}$ & $63.68 \pm 0.19$ & $\begin{array}{c}11.821 \pm \\
0.035\end{array}$ & $61.36 \pm 0.12$ & $\begin{array}{c}1.1178 \pm \\
0.0021\end{array}$ & $\begin{array}{c}1.0333 \pm \\
0.0052\end{array}$ & $\begin{array}{c}1.1550 \pm \\
0.0054\end{array}$ & $\begin{array}{c}1.1255 \pm \\
0.0077\end{array}$ & $\begin{array}{c}0.9961 \pm \\
0.0085\end{array}$ \\
\hline \multicolumn{11}{|l|}{ Fracture C } \\
\hline NOPI-376 & 0.0 & $\begin{array}{c}24.399 \pm \\
0.081\end{array}$ & $\begin{array}{c}163.32 \pm \\
0.61\end{array}$ & $30.32 \pm 0.11$ & $64.86 \pm 0.12$ & $\begin{array}{c}1.1815 \pm \\
0.0022\end{array}$ & $\begin{array}{c}1.0542 \pm \\
0.0056\end{array}$ & $\begin{array}{c}1.2455 \pm \\
0.0062\end{array}$ & $\begin{array}{c}0.8773 \pm \\
0.0086\end{array}$ & - \\
\hline \multicolumn{11}{|l|}{ Fracture E } \\
\hline NOPI-403 & 0.0 & $\begin{array}{c}23.692 \pm \\
0.084\end{array}$ & $\begin{array}{c}143.51 \pm \\
0.55\end{array}$ & $26.64 \pm 0.10$ & $57.672 \pm 0.092$ & $\begin{array}{c}1.0507 \pm \\
0.0017\end{array}$ & $\begin{array}{c}1.0702 \pm \\
0.0058\end{array}$ & $\begin{array}{c}1.1244 \pm \\
0.0058\end{array}$ & - & $\begin{array}{c}0.9937 \pm \\
0.0079\end{array}$ \\
\hline NOPI-404 & 1.7 & $\begin{array}{c}11.041 \pm \\
0.037\end{array}$ & $73.21 \pm 0.59$ & $13.59 \pm 0.11$ & $63.990 \pm 0.064$ & $\begin{array}{c}1.1658 \pm \\
0.0012 \\
\end{array}$ & $\begin{array}{c}1.0558 \pm \\
0.0092 \\
\end{array}$ & $1.231 \pm 0.011$ & - & - \\
\hline NOPI-407 & 7.6 & $\begin{array}{c}36.85 \pm \\
0.13\end{array}$ & $\begin{array}{c}189.20 \pm \\
0.45\end{array}$ & $\begin{array}{c}35.121 \pm \\
0.083\end{array}$ & $51.786 \pm 0.093$ & $\begin{array}{c}0.9434 \pm \\
0.0017\end{array}$ & $\begin{array}{c}1.0102 \pm \\
0.0047\end{array}$ & $\begin{array}{c}0.9531 \pm \\
0.0041\end{array}$ & $\begin{array}{c}0.7362 \pm \\
0.0082\end{array}$ & $\begin{array}{c}1.0059 \pm \\
0.0081\end{array}$ \\
\hline NOPI-410 & 38.7 & $\begin{array}{c}0.9099 \pm \\
0.0032\end{array}$ & $\begin{array}{c}5.839 \pm \\
0.023\end{array}$ & $\begin{array}{c}1.0829 \pm \\
0.0043\end{array}$ & $63.77 \pm 0.11$ & $\begin{array}{c}1.1618 \pm \\
0.0021\end{array}$ & $\begin{array}{c}1.0253 \pm \\
0.0058\end{array}$ & $\begin{array}{c}1.1912 \pm \\
0.0064\end{array}$ & - & $\begin{array}{c}0.9989 \pm \\
0.0073\end{array}$ \\
\hline NOPI-411 & 38.7 & $1.2366 \pm$ & $9.183 \pm$ & $1.7047 \pm$ & $73.33 \pm 0.12$ & $1.3360 \pm$ & $1.0318 \pm$ & $1.3785 \pm$ & - & $0.9991 \pm$ \\
\hline
\end{tabular}




\begin{tabular}{|c|c|c|c|c|c|c|c|c|c|c|}
\hline & & 0.0047 & 0.040 & 0.0074 & & 0.0021 & 0.0062 & 0.0080 & & 0.0088 \\
\hline \multicolumn{11}{|l|}{ Fracture $\mathbf{F}$} \\
\hline NOPI-309-sd1 & 0.0 & $\begin{array}{c}110.91 \pm \\
0.36\end{array}$ & $623.4 \pm 1.2$ & $\begin{array}{c}115.72 \pm \\
0.23\end{array}$ & $59.19 \pm 0.11$ & $\begin{array}{c}1.0783 \pm \\
0.0019\end{array}$ & $\begin{array}{c}0.9676 \pm \\
0.0041\end{array}$ & $\begin{array}{c}1.0434 \pm \\
0.0040\end{array}$ & $\begin{array}{c}0.997 \pm \\
0.013\end{array}$ & $\begin{array}{c}0.9799 \pm \\
0.0066\end{array}$ \\
\hline NOPI-309-sd2 & 0.0 & $\begin{array}{c}110.86 \pm \\
0.41\end{array}$ & $622.9 \pm 3.1$ & $\begin{array}{c}115.62 \pm \\
0.58\end{array}$ & $59.29 \pm 0.11$ & $\begin{array}{c}1.0802 \pm \\
0.0019\end{array}$ & $\begin{array}{c}0.9656 \pm \\
0.0063\end{array}$ & $\begin{array}{c}1.0430 \pm \\
0.0065\end{array}$ & - & $\begin{array}{c}0.9893 \pm \\
0.0069\end{array}$ \\
\hline NOPI-320 & 6.3 & $\begin{array}{c}46.80 \pm \\
0.18\end{array}$ & $\begin{array}{c}140.48 \pm \\
0.41\end{array}$ & $\begin{array}{c}26.076 \pm \\
0.076\end{array}$ & $53.839 \pm 0.075$ & $\begin{array}{c}0.9808 \pm \\
0.0014\end{array}$ & $\begin{array}{c}0.5681 \pm \\
0.0028\end{array}$ & $\begin{array}{c}0.5572 \pm \\
0.0026\end{array}$ & - & $\begin{array}{c}0.6435 \pm \\
0.0051\end{array}$ \\
\hline \multicolumn{11}{|c|}{ Standards } \\
\hline TML-97B-sd1 & & $\begin{array}{c}1.0889 \pm \\
0.0040\end{array}$ & $\begin{array}{c}5.862 \pm \\
0.021\end{array}$ & $\begin{array}{c}1.0882 \pm \\
0.0039\end{array}$ & $54.959 \pm 0.077$ & $\begin{array}{c}1.0013 \pm \\
0.0014\end{array}$ & $\begin{array}{c}0.9981 \pm \\
0.0053\end{array}$ & $\begin{array}{c}0.9993 \pm \\
0.0051\end{array}$ & $\begin{array}{c}1.0038 \pm \\
0.0067\end{array}$ & - \\
\hline TML-97B-sd2 & & $\begin{array}{c}1.0817 \pm \\
0.0035\end{array}$ & $\begin{array}{c}5.803 \pm \\
0.027\end{array}$ & $\begin{array}{c}1.0772 \pm \\
0.0050\end{array}$ & $54.980 \pm 0.077$ & $\begin{array}{c}1.0016 \pm \\
0.0014\end{array}$ & $\begin{array}{c}0.9942 \pm \\
0.0057\end{array}$ & $\begin{array}{c}0.9958 \pm \\
0.0056\end{array}$ & $\begin{array}{c}0.9996 \pm \\
0.0078\end{array}$ & $\begin{array}{c}0.9921 \pm \\
0.0062\end{array}$ \\
\hline BL4 & & $\begin{array}{c}427.0 \pm \\
1.5\end{array}$ & $2291 \pm 18$ & $425.2 \pm 3.4$ & $54.963 \pm 0.049$ & $\begin{array}{c}1.00132 \pm \\
0.00090\end{array}$ & $\begin{array}{c}0.9945 \pm \\
0.0087\end{array}$ & $\begin{array}{c}0.9958 \pm \\
0.0087\end{array}$ & $\begin{array}{c}1.016 \pm \\
0.010\end{array}$ & $\begin{array}{c}0.9978 \pm \\
0.0066\end{array}$ \\
\hline
\end{tabular}

Parentheses denote activities. Uncertainties are expressed as 2xSEM (absolute). Half-lives used in calculations are specified in Table 1. 
Table $4{ }^{230} \mathrm{Th}_{-}{ }^{234} \mathrm{U}_{-}^{238} \mathrm{U}$ and ${ }^{231} \mathrm{~Pa}-{ }^{235} \mathrm{U}$ model ages for the drill core and surface fracture samples and the rock standards.

\begin{tabular}{|c|c|c|c|}
\hline \multicolumn{4}{|c|}{ Drill core samples } \\
\hline Sample & $\begin{array}{c}\text { Distance from } \\
\text { Surface (m) }\end{array}$ & $\begin{array}{l}{ }^{230} \mathrm{Th}-{ }^{234} \mathrm{U}-{ }^{238} \mathrm{U} \\
\text { Model Age (ka) }\end{array}$ & $\begin{array}{c}{ }^{231} \mathrm{~Pa}^{235} \mathrm{U} \text { Model } \\
\text { Age (ka) }\end{array}$ \\
\hline PB1023774-1 & 8.5 & $461(+491,-437)$ & - \\
\hline PB1023774-2 & 8.5 & $427(+445,-407)$ & - \\
\hline PB1023774-3 & 8.5 & $504(+545,-470)$ & - \\
\hline PB1023849-1 & 67.0 & $206(+208,-204)$ & - \\
\hline PB1023849-2 & 67.0 & $259(+263,-255)$ & - \\
\hline PB1023849-3-pd1 & 67.0 & $\mathrm{fz}(+\mathrm{fz},-\mathrm{fz})$ & - \\
\hline PB1023849-3-pd2 & 67.0 & $f z(+f z,-f z)$ & - \\
\hline PB1024009-1 & 191.0 & $245(+248,-241)$ & - \\
\hline PB1024009-2 & 191.0 & $199(+202,-197)$ & - \\
\hline PB1024009-3 & 191.0 & $183(+185,-181)$ & - \\
\hline PB1024009-4 & 191.0 & $211(+214,-208)$ & - \\
\hline \multicolumn{4}{|c|}{ Surface fracture samples } \\
\hline Sample & $\begin{array}{c}\text { Distance from origin } \\
\text { of fracture (m) }\end{array}$ & $\begin{array}{l}{ }^{230} \mathrm{Th}-{ }^{234} \mathrm{U}-{ }^{238} \mathrm{U} \\
\text { Model Age (ka) }\end{array}$ & $\begin{array}{c}{ }^{231} \mathrm{~Pa}^{235} \mathrm{U} \text { Model } \\
\text { Age (ka) }\end{array}$ \\
\hline \multicolumn{4}{|l|}{ Fracture B } \\
\hline NOPI-418-pd1 & 0.0 & $381(+405,-363)$ & $214(+281,-187)$ \\
\hline NOPI-418-pd2 & 0.0 & $379(+399,-365)$ & $221(+318,-192)$ \\
\hline NOPI-419-sd1 & 2.7 & $314(+323,306)$ & $272(+\mathrm{fz},-214)$ \\
\hline NOPI-419-sd2 & 2.7 & - & $\mathrm{fz}(+\mathrm{fz},-287)$ \\
\hline NOPI-420-pd1 & 5.5 & $443(+374,-330)$ & $198(+232,-178)$ \\
\hline NOPI-420-pd2 & 5.5 & $461(+433,-441)$ & - \\
\hline NOPI-421-1 & 8.5 & $418(+443,-393)$ & 231 (+fz, -197) \\
\hline NOPI-421-2 & 8.5 & $432(+453,-411)$ & - \\
\hline NOPI-423-1 & 13.8 & $437(+460,-419)$ & $f z(+f z,-244)$ \\
\hline NOPI-423-2 & 13.8 & $538(+574,-493)$ & $223(+279,-198)$ \\
\hline NOPI-424-sd1 & 17.8 & - & $f z(+f z,-243)$ \\
\hline NOPI-424-sd2 & 17.8 & - & - \\
\hline NOPI-424-sd3 & 17.8 & $423(+454,-403)$ & - \\
\hline NOPI-425-1 & 21.5 & $462(+512,-433)$ & $278(+\mathrm{fz},-210)$ \\
\hline NOPI-425-2 & 21.5 & $516(+571,-481)$ & $262(+\mathrm{fz},-208)$ \\
\hline \multicolumn{4}{|l|}{ Fracture C } \\
\hline NOPI-376 & 0.0 & $531(+588,-495)$ & - \\
\hline \multicolumn{4}{|l|}{ Fracture E } \\
\hline NOPI-403 & 0.0 & $\mathrm{fz}(+\mathrm{fz},-\mathrm{fz})$ & $240(+\mathrm{fz}, 201)$ \\
\hline NOPI-404 & 1.7 & $613(+\mathrm{fz},-500)$ & - \\
\hline NOPI-407 & 7.6 & $\mathrm{fz}(+\mathrm{fz},-\mathrm{fz})$ & $f z(+f z,-289)$ \\
\hline NOPI-410 & 38.7 & $405(+424,-385)$ & $322(+\mathrm{fz},-226)$ \\
\hline
\end{tabular}




\begin{tabular}{|c|c|c|c|}
\hline NOPI-411 & 38.7 & $331(+341,-322)$ & $332(+\mathrm{fz},-219)$ \\
\hline \multicolumn{4}{|l|}{ Fracture F } \\
\hline NOPI-309-sd1 & 0.0 & $316(+323,-310)$ & $185(+204,-171)$ \\
\hline NOPI-309-sd2 & 0.0 & $313(+323,-303)$ & $215(+264,-191)$ \\
\hline NOPI-320 & 6.3 & $92(+93,-91)$ & $49(+46,-48)$ \\
\hline \multicolumn{4}{|c|}{ Standards } \\
\hline TML-97B-sd1 & & $637(+f z,-525)$ & - \\
\hline TML-97B-sd2 & & $541(+662,-481)$ & $229(+299,-201)$ \\
\hline BL4 & & $560(+\mathrm{fz},-460)$ & $290(+f z,-224)$ \\
\hline
\end{tabular}

The model age uncertainties are expressed as an upper and lower bound at the 2xSEM confidence interval, and $\mathrm{fz}=$ forbidden zone with undefined model age. Only samples with $\mathrm{fz}$ $(+\mathrm{fz},-\mathrm{fz})$ are considered to be in the forbidden zone 


\section{Appendix}

Table A1 Details of the samples analyzed as part of this study. Information for the samples from the surface fractures includes location, distance from the deposit and the name of the fracture located in Figure 2. Information for the drill core samples analyzed as part of this study includes the drill core name, depth from the ore deposit and the minerals identified in the sample by XRD. The italic information under the sample name for the drill core samples indicates the sub-sample identifier (e.g. -1) and the color of the fraction.

\begin{tabular}{|c|c|c|c|}
\hline \multicolumn{4}{|c|}{ Surface fractures } \\
\hline Sample & Location & $\begin{array}{l}\text { Distance from } \\
\text { origin of } \\
\text { fracture (m) }\end{array}$ & Fracture \\
\hline NOPI-418-pd1 & $\begin{array}{c}X=11.7, Y=13.3 \\
Z=10\end{array}$ & 0.0 & B \\
\hline NOPI-418-pd2 & & 0.0 & $\mathrm{~B}$ \\
\hline NOPI-419-sd1 & $\begin{array}{c}X=9, Y=13.8, \\
Z=10\end{array}$ & 2.7 & B \\
\hline NOPI-419-sd2 & & 2.7 & B \\
\hline NOPI-420-pd1 & $\begin{array}{c}X=6.2, Y=13.95 \\
Z=10\end{array}$ & 5.5 & B \\
\hline NOPI-420-pd2 & & 5.5 & B \\
\hline NOPI-421-1 & $\begin{array}{c}\mathrm{X}=3.2, \mathrm{Y}=13.6 \\
\mathrm{Z}=10\end{array}$ & 8.5 & B \\
\hline NOPI-421-2 & & 8.5 & B \\
\hline NOPI-423-1 & $\begin{array}{c}X=-2.1, Y=14.1 \\
Z=10\end{array}$ & 13.8 & B \\
\hline NOPI-423-2 & & 13.8 & $\mathrm{~B}$ \\
\hline NOPI-424-sd1 & $\begin{array}{c}\mathrm{X}=-6.1 \\
\mathrm{Y}=13.95, \mathrm{Z}=10\end{array}$ & 17.8 & B \\
\hline NOPI-424-sd2 & & 17.8 & B \\
\hline NOPI-424-sd3 & & 17.8 & B \\
\hline NOPI-425-1 & $\begin{array}{c}X=-9.8, Y=14.6 \\
Z=10\end{array}$ & 21.5 & $\mathrm{~B}$ \\
\hline NOPI-425-2 & & 21.5 & $\mathrm{~B}$ \\
\hline NOPI-376 & $\begin{array}{c}\mathrm{X}=17.95 \\
\mathrm{Y}=14.05, \mathrm{Z}=10\end{array}$ & 0.0 & $\mathrm{C}$ \\
\hline NOPI-403 & $\begin{array}{c}X=33.9, Y=21.2 \\
Z=10\end{array}$ & 0.0 & $\mathrm{E}$ \\
\hline NOPI-404 & $\begin{array}{c}X=35.4, Y=20.5 \\
Z=10\end{array}$ & 1.7 & $\mathrm{E}$ \\
\hline NOPI-407 & $\begin{array}{c}X=41.1, Y=18.8 \\
Z=10\end{array}$ & 7.6 & E \\
\hline NOPI-410 & $\begin{array}{c}X=15, Y=55, \\
Z=22.5\end{array}$ & 38.7 & $\mathrm{E}$ \\
\hline NOPI-411 & $X=15, Y=55$ & 38.7 & $\mathrm{E}$ \\
\hline
\end{tabular}




\begin{tabular}{|c|c|c|c|}
\hline & $\mathrm{Z}=22.5$ & & \\
\hline NOPI-309-sd1 & $\begin{array}{c}X=26.55, Y=- \\
7.7, Z=0\end{array}$ & 0.0 & $\mathrm{~F}$ \\
\hline NOPI-309-sd2 & & 0.0 & $\mathrm{~F}$ \\
\hline NOPI-320 & $\begin{array}{c}\mathrm{X}=31.1, \mathrm{Y}=-12, \\
\mathrm{Z}=0\end{array}$ & 6.3 & $\mathrm{~F}$ \\
\hline \multicolumn{4}{|c|}{ Drill core samples } \\
\hline Sample & Location & $\begin{array}{l}\text { Distance from } \\
\text { surface (m) }\end{array}$ & $\begin{array}{c}\text { Minerals } \\
\text { present }\end{array}$ \\
\hline $\begin{array}{c}\text { PB1023774 } \\
{[-1 \text { (mix), }-2 \text { (dark), }-3 \text { (light) }]}\end{array}$ & PB-1 core & 8.5 & $\begin{array}{c}\text { Goethite, } \\
\text { hematite, } \\
\text { kaolinite, quartz }\end{array}$ \\
\hline $\begin{array}{c}\text { PB1023849 } \\
{[-1 \text { (dark), }-2(\text { mix }),-3 p d 1} \\
\text { (light), }-3 p d 2(\text { light })]\end{array}$ & PB-1 core & 67.0 & $\begin{array}{c}\text { hematite, } \\
\text { kaolinite, quartz }\end{array}$ \\
\hline $\begin{array}{c}\text { PB1024009 } \\
{[-1 \text { (vein) },-2(\text { light }),-3} \\
(\text { light }),-4(\text { nodule })]\end{array}$ & PB-1 core & 191.0 & $\begin{array}{l}\text { kaolinite, quartz, } \\
\text { calcite, dolomite }\end{array}$ \\
\hline
\end{tabular}

